\title{
Article \\ Decellularized Porcine Cartilage Scaffold; Validation of Decellularization and Evaluation of Biomarkers of Chondrogenesis
}

\author{
Roxanne N. Stone ${ }^{1,2}$, Stephanie M. Frahs ${ }^{2,3,4}$, Makenna J. Hardy 2,3,4 $\mathbb{D}_{\text {, Akina Fujimoto }}^{2,3}$, Xinzhu Pu 2,3,4, \\ Cynthia Keller-Peck ${ }^{2,3}$ and Julia Thom Oxford $2,3,4,5, *$ iD \\ 1 Interdisciplinary Studies Program, Boise State University, Boise, ID 83725, USA; \\ roxannestone@u.boisestate.edu \\ 2 Biomolecular Research Center, Boise State University, Boise, ID 83725, USA; \\ StephanieTuft@boisestate.edu (S.M.F.); makennahardy@u.boisestate.edu (M.J.H.); \\ akinafujimoto@boisestate.edu (A.F.); shinpu@boisestate.edu (X.P.); ckpeck@boisestate.edu (C.K.-P.) \\ 3 Center of Biomedical Research Excellence in Matrix Biology, Boise State University, Boise, ID 83725, USA \\ 4 Biomolecular Sciences Graduate Programs, Boise State University, Boise, ID 83725, USA \\ 5 Department of Biological Sciences, Boise State University, Boise, ID 83725, USA \\ * Correspondence: joxford@boisestate.edu; Tel.: +01-208-426-2395
}

check for updates

Citation: Stone, R.N.; Frahs, S.M.; Hardy, M.J.; Fujimoto, A.; Pu, X.;

Keller-Peck, C.; Oxford, J.T.

Decellularized Porcine Cartilage

Scaffold; Validation of

Decellularization and Evaluation of Biomarkers of Chondrogenesis. Int. J. Mol. Sci. 2021, 22, 6241. https:// doi.org/10.3390/ijms22126241

Academic Editor: Frank Zaucke

Received: 4 May 2021

Accepted: 4 June 2021

Published: 9 June 2021

Publisher's Note: MDPI stays neutral with regard to jurisdictional claims in published maps and institutional affiliations.

Copyright: (c) 2021 by the authors. Licensee MDPI, Basel, Switzerland. This article is an open access article distributed under the terms and conditions of the Creative Commons Attribution (CC BY) license (https:// creativecommons.org/licenses/by/ $4.0 /)$.
Abstract: Osteoarthritis is a major concern in the United States and worldwide. Current non-surgical and surgical approaches alleviate pain but show little evidence of cartilage restoration. Cell-based treatments may hold promise for the regeneration of hyaline cartilage-like tissue at the site of injury or wear. Cell-cell and cell-matrix interactions have been shown to drive cell differentiation pathways. Biomaterials for clinically relevant applications can be generated from decellularized porcine auricular cartilage. This material may represent a suitable scaffold on which to seed and grow chondrocytes to create new cartilage. In this study, we used decellularization techniques to create an extracellular matrix scaffold that supports chondrocyte cell attachment and growth in tissue culture conditions. Results presented here evaluate the decellularization process histologically and molecularly. We identified new and novel biomarker profiles that may aid future cartilage decellularization efforts. Additionally, the resulting scaffold was characterized using scanning electron microscopy, fluorescence microscopy, and proteomics. Cellular response to the decellularized scaffold was evaluated by quantitative real-time PCR for gene expression analysis.

Keywords: cartilage; chondrocytes; decellularized; scaffold; proteomics; real time quantitative PCR; histology; scanning electron microscopy; C28/I2 cells; porcine auricular cartilage

\section{Introduction}

Osteoarthritis (OA) is defined as a chronic, debilitating, and painful disease. It is estimated to be one of the leading causes of disability worldwide [1-4]. Sports, recreational activities, and even daily movements can contribute to the formation of cartilage lesions. Lesions or chondral defects, when left untreated, can lead to degenerative joint disease that may include an inflammatory response [4,5].

Knee OA is the most common type of OA and accounts for $70 \%$ of arthritis-related hospital admissions and $23 \%$ of clinical visits [2]. Given the anatomical position of the knee, it acts as a shock absorber by withstanding both tension and compression [6]. Hyaline cartilage within articular joints is located at the ends of long bones. Cartilage lacks nerve fibers and is avascular. It is tough, but flexible, and contains large amounts of glycosaminoglycans (GAGs) such as chondroitin sulfate and hyaluronic acid (HA), which interact with type II/IX/XI heterotypic collagen fibrils. Proteoglycans, such as aggrecan, are predominant molecular constituents of articular cartilage $[2,4,7]$. 
The precisely organized architecture of the extracellular matrix (ECM) provides the normal structural integrity of tissues. The function of the articular cartilage is to protect the subchondral bone from mechanical forces by distributing the load equally while maintaining low friction across the joint surfaces $[2,4,7]$. While normal healthy cartilage supports tissue homeostasis and chondrocyte function, osteoarthritic cartilage does not effectively carry out the functions of maintaining cartilage homeostasis and cellular differentiation [4].

Chondrocytes are the predominant cell type in growing cartilage. These cells produce new ECM until the skeleton stops growing at adolescence. Mature chondrocytes rarely divide and have limited ability to proliferate. Chondrocytes have been shown to decrease with age, which may explain, in part, why cartilage lesions do not spontaneously heal $[4,6,8]$. Older adults, aged 50 and older, are at an increased risk for knee OA and this may be due in part to hormonal changes that are associated with biological aging in the chondrocytes [2]. Osteoarthritic cartilage does not effectively carry out the functions of normal healthy cartilage and treatment options are limited [2,4]. Articular cartilage degeneration begins at the surface and leads to the onset of fibrillation, which disrupts the molecular framework of the ECM $[9,10]$. These changes may be triggered by mechanical damage or wear and tear of the tissue [11]. The collagen fibrils disorient beneath the surface and a decrease in HA and aggrecan have been reported [12,13]. A better understanding of the cartilage degeneration and regeneration mechanisms would be useful to help develop new potential treatment strategies to repair damaged cartilage. Currently, the primary treatment option for knee OA is full knee replacement [2].

Cell-based strategies provide an alternative to full knee replacement; however, the major limitation to current recellularization approaches through cell therapy is that the outcome is often the formation of fibrocartilage rather than the desired hyaline cartilage [14-16]. Additionally, cell retention within the target area is a challenge, and in some cases, cells move to other parts of the body $[2,6,8]$. A suitable scaffold may alleviate this problem. Current scaffolds used for cartilage regeneration include synthetic and natural materials. Natural materials include agarose, alginate, chitosan, collagen, fibrin, and hyaluronan. Synthetic polymers include polylactic acid (PLA), polyglycolic acid (PGA), and their copolymer polylactic-co-glycolic acid (PLGA). Scaffolds used in tissue engineering approaches for cartilage regeneration have recently been reviewed in Huang et al. [17]. Hybrid approaches have been used in which cartilage insets are placed within a 3D-printed scaffold [18], showing promising results histologically. Biomaterials designed with improved cell adhesion that can promote differentiation leading to healing in the damaged tissue can supplement cell-based approaches for the treatment of cartilage lesions and OA treatment $[2,4,5]$.

In this study, decellularization strategies for cartilage were evaluated based on their ability to remove DNA and other cellular material while preserving extracellular matrix components of the original tissue. We performed decellularization using a combination of chemical and physical methods. Surfactants, acid and bases, and enzymes were included in the chemical and enzymatic treatment to remove cells [19-21]. Following decellularization, C28/I2 human chondrocytes, which were established by transfection of primary cultures of juvenile costal chondrocytes [22], were seeded onto the scaffold and the cellular response to the scaffold was evaluated.

\section{Results}

After removal of all tissue from the surface of the cartilage, the cartilage tissue was revealed as shown in Figure 1a. Discs of $8 \mathrm{~mm}$ diameter and $1.08 \mathrm{~mm}$ thickness were created from the larger cartilage (Figure 1b). 


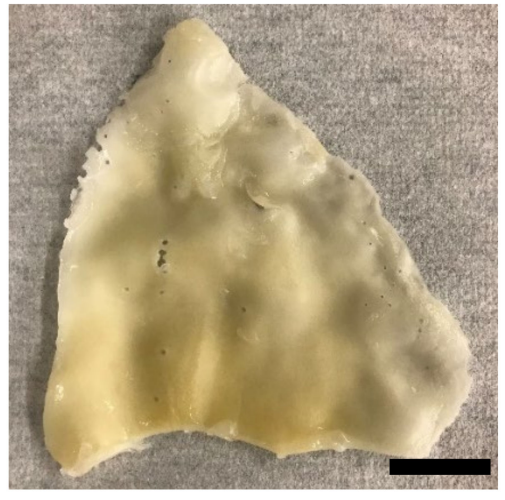

(a)

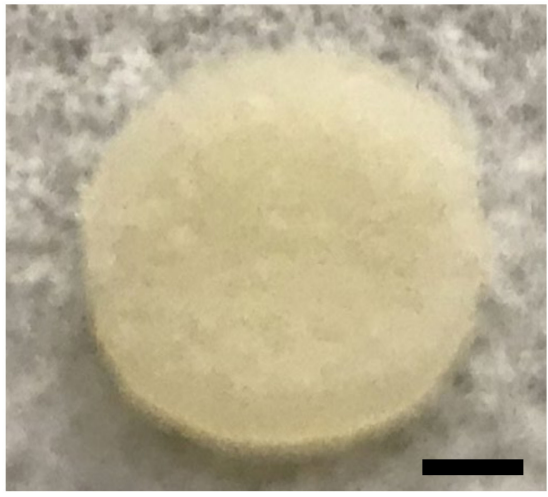

(b)

Figure 1. Cartilage scaffold resulting from decellularization process: (a) porcine auricular cartilage after dissection and initial processing; (b) $8 \mathrm{~mm}$ diameter cartilage disc after decellularization process was complete. Discs of decellularized cartilage were formed using an $8 \mathrm{~mm}$ diameter biopsy punch. Scale bars: (a) $30 \mathrm{~mm}$; (b) $2 \mathrm{~mm}$.

After a subsequent $24 \mathrm{~h}$ hyaluronidase treatment [23], followed by a $24 \mathrm{~h} 37^{\circ} \mathrm{C}$ DNase and RNase treatment $[19,23]$, we evaluated the tissues by histology and scanning electron microscopy. Freeze-thaw cycles were repeated followed by DI water incubation, and SDS treatment at $37^{\circ} \mathrm{C}$, with subsequent DNase digestion for $72 \mathrm{~h}$ at $37^{\circ} \mathrm{C}$ with agitation. The overall decellularization process is depicted in Figure 2. Results from histological analysis are shown in Figure 3a,b. Histological analysis showed a decrease in cellular structures with the preservation of the extracellular matrix. Hoechst staining showed DNA content to be reduced (Figure 3c,d).

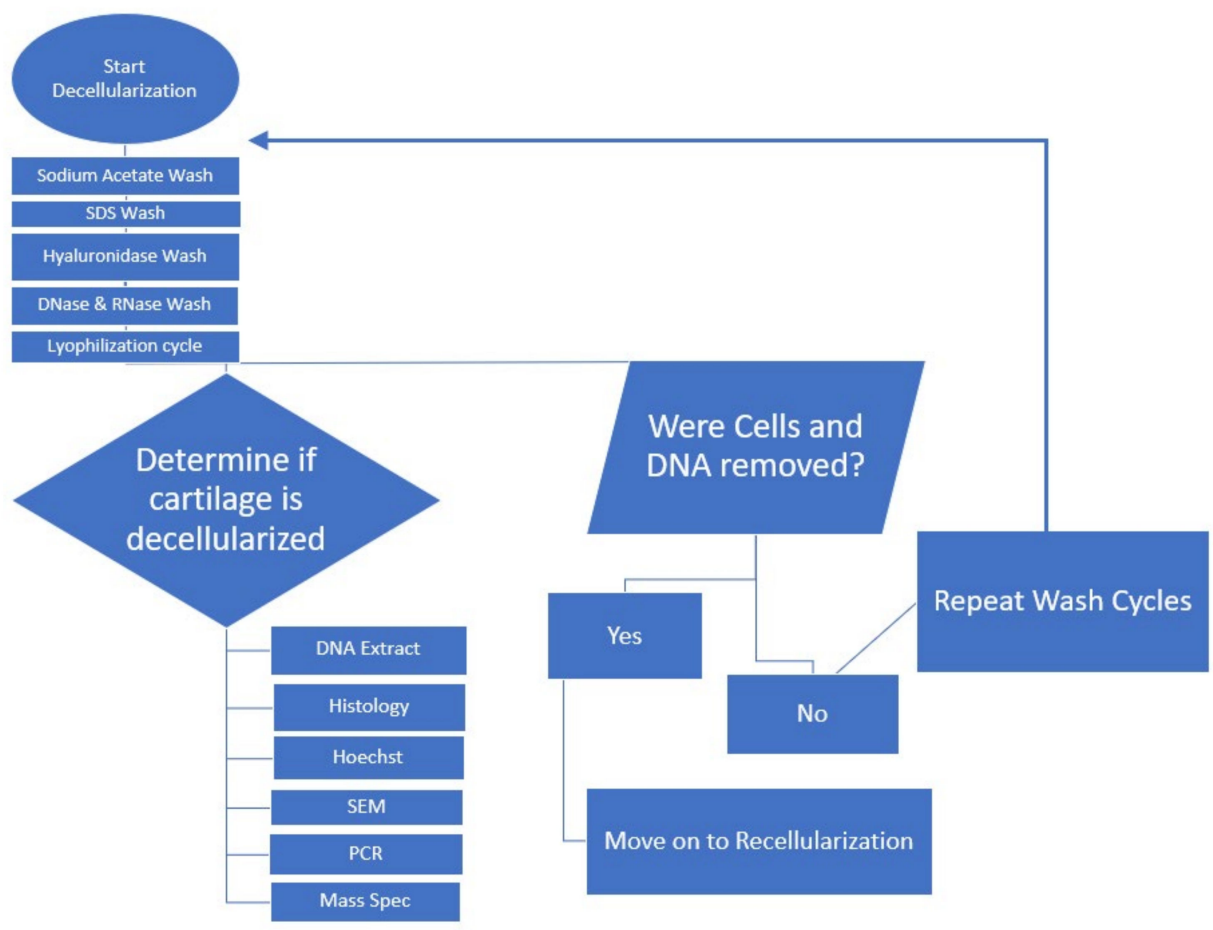

Figure 2. Flowchart for decellularization process. 


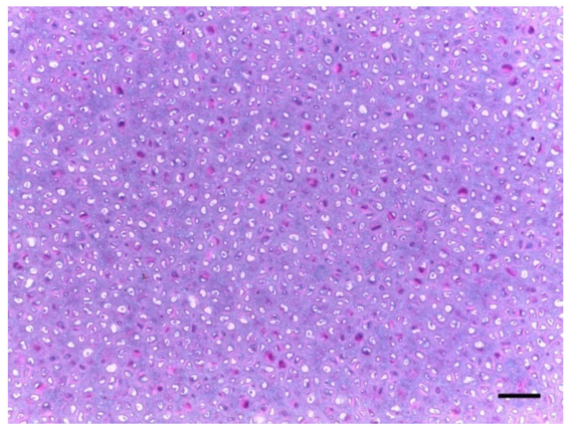

(a)

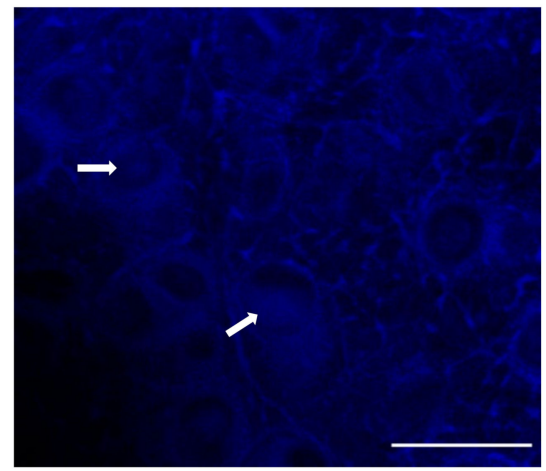

(c)

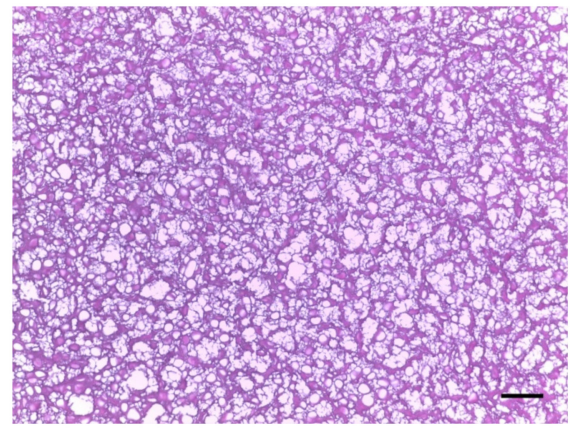

(b)

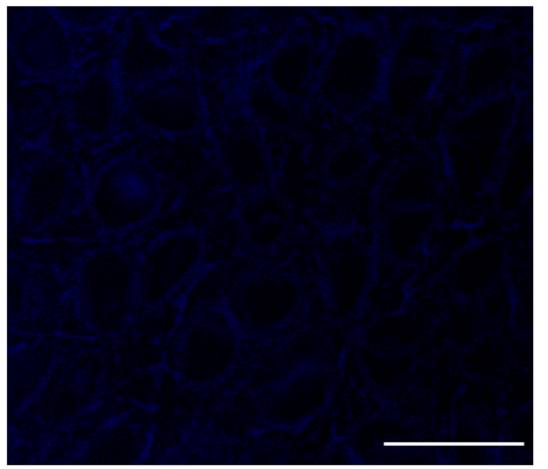

(d)

Figure 3. Visualization of cartilage tissue by histology. (a) Nondecellularized porcine cartilage stained with $\mathrm{H} \& \mathrm{E}, 10 \times$ transverse image. (b) H\&E stain on final decellularized cartilage, transverse image. (c) Hoechst stain to fluorescently visualize DNA (blue). Arrows indicate nuclei. (d) Hoechst stain shows absence of DNA after decellularization process (see absence of blue). Scale bar $=100 \mu \mathrm{m}$ for $(\mathbf{a}, \mathbf{b})$; scale bar $=50 \mu \mathrm{m}$ for $(\mathbf{c}, \mathbf{d})$.

To quantify the depletion of DNA in the samples, samples were subjected to a DNA extraction process before and after decellularization. We found that the decellularization process removed $98.8 \%$ of the DNA associated with cells (Figure 4 ).

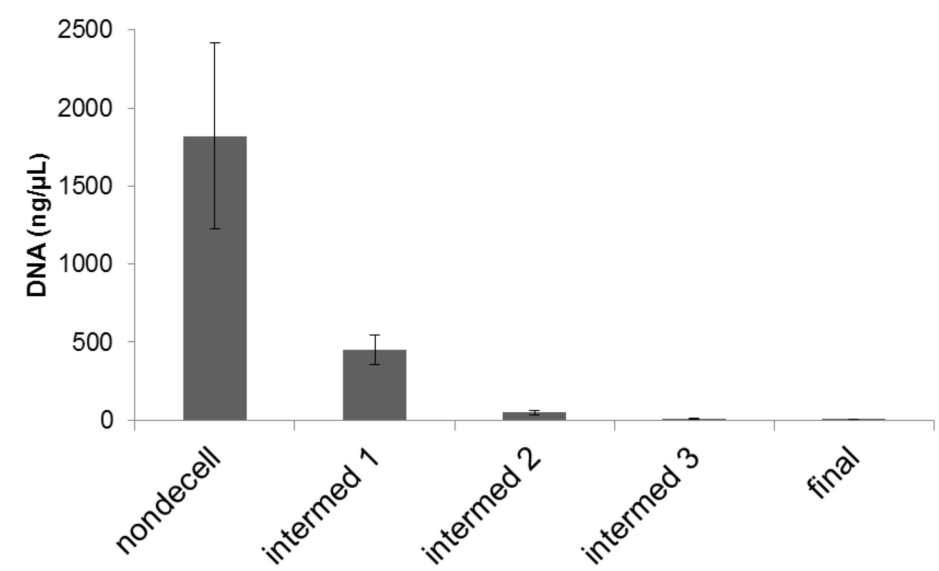

Figure 4. DNA content before, during sequential stages, and after decellularization process. DNA was extracted and quantified spectrophotometrically. Quantitative measurements of DNA within scaffolds before, during, and after decellularization process indicated that residual DNA was at approximately $24.76 \%, 2.63 \%, 0.66 \%$, and finally $0.22 \%$ of the original content. Error bars: Mean \pm standard error of the mean. $\mathrm{N}=6$. 
Scanning electron microscopy was performed to monitor tissue throughout the decellularization process. Surface features are visualized in Figure 5. Prior to the decellularization process, cells, although present within the tissue, are not visible at the surface of the cartilage samples at either low (Figure 5a) or high magnification (Figure 5b). The surface features revealed by the decellularization process and scanning electron microscopy demonstrate an increase in surface complexity and exposure of the collagenous fibrillar matrix existing within the tissue (Figure $5 c, d$ ).

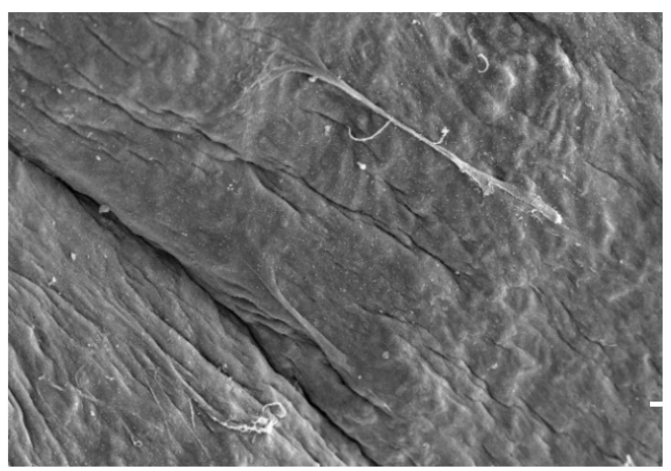

(a)

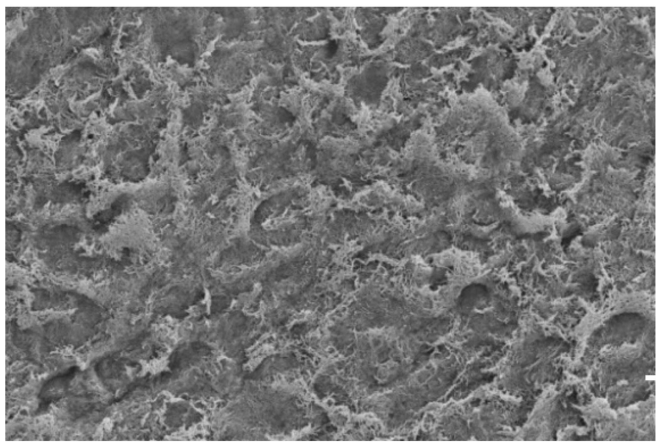

(c)

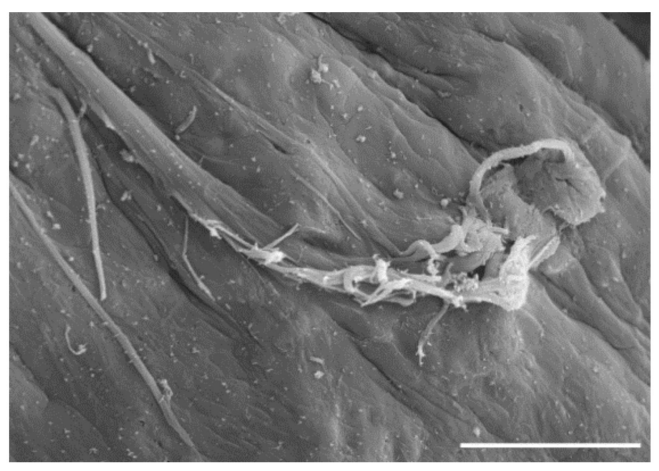

(b)

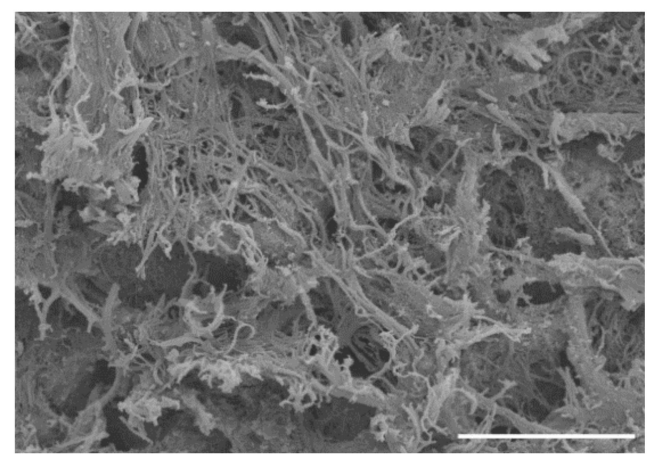

(d)

Figure 5. Visualization of cartilage by scanning electron microscopy. (a) Cartilage prior to treatment; (b) higher magnification of cartilage prior to treatment, where the tissue appears smooth and intact; (c) final decellularized cartilage disc; (d) higher magnification of decellularized cartilage disc. Appearance after decellularization indicates a rough surface with increased surface area and exposed collagen fibrillar networks. Scale bars $=20 \mu \mathrm{m}$.

To complement the analysis of DNA depletion after treatment, we carried out mass spectrometry to analyze the protein content of the scaffold before and after treatment for decellularization. Nuclear proteins were considered for their potential as suitable biomarkers for decellularization. We investigated a profile of 20 nuclear proteins that included APTX, UIMC1, DMRT1, H3F3A, MX1, ISG20, IREB2, MYOCD, NFATC1, NROB1, PTBP1, POU5F, SORBS2, SRPK3, SREBF1, HISTONE H4, STAT5A, HNF1B, DHX16, and RAG1. Of these, 15 were depleted to a level that rendered them no longer detectable by mass spectrometry. Five of these (HISTONE H4, STAT5A, HNF1B, DHX16, and RAG1) were depleted by $83-96 \%$, indicating that there may be biochemical interactions mediating molecular interactions independent of the cellular compartment. We propose a nuclear protein profile of 15 proteins that may be used to assess and evaluate the efficiency of the decellularization process. The nuclear proteins comprising this profile are listed in Table 1. 
Table 1. Proteomic analysis of proteins removed by decellularization.

\begin{tabular}{|c|c|c|}
\hline Nuclear Proteins Depleted by Decellularization Process & \% Depletion & Gene Symbol \\
\hline Aprataxin & 100 & APTX \\
\hline BRCA1-A complex subunit RAP80 & 100 & UIMC1 \\
\hline Doublesex- and mab-3-related transcription factor 1 & 100 & DMRT1 \\
\hline Histone $\mathrm{H} 3.3$ & 100 & H3F3A \\
\hline Interferon-induced GTP-binding protein Mx1 & 100 & MX1 \\
\hline Interferon-stimulated gene $20 \mathrm{kDa}$ protein & 100 & ISG20 \\
\hline Iron-responsive element-binding protein 2 & 100 & IREB2 \\
\hline Myocardin & 100 & MYOCD \\
\hline Nuclear factor of activated T-cells, cytoplasmic 1 & 100 & NFATC1 \\
\hline Nuclear receptor subfamily 0 group B member 1 & 100 & NR0B1 \\
\hline Polypyrimidine tract-binding protein 1 & 100 & PTBP1 \\
\hline POU domain, class 5 , transcription factor 1 & 100 & POU5F1 \\
\hline Sorbin and $\mathrm{SH} 3$ domain-containing protein 2 & 100 & SORBS2 \\
\hline SRSF protein kinase 3 & 100 & SRPK3 \\
\hline Sterol regulatory element-binding protein 1 & 100 & SREBF1 \\
\hline Histone $\mathrm{H} 4$ & 96 & Histone $\mathrm{H} 4$ \\
\hline Signal transducer and activator of transcription $5 \mathrm{~A}$ & 89 & STAT5A \\
\hline Hepatocyte nuclear factor 1-beta & 85 & HNF1B \\
\hline Pre-mRNA-splicing factor ATP-dependent RNA helicase DHX16 & 85 & DHX16 \\
\hline V(D)J recombination-activating protein 1 & 83 & RAG1 \\
\hline
\end{tabular}

In addition to nuclear biomarkers, we also analyzed organellar cellular proteins including those associated with mitochondria, Golgi, and endoplasmic reticulum. We investigated five Golgi-specific proteins, 29 mitochondrial proteins, and 20 endoplasmic reticulum proteins that were depleted as a result of the decellularization process. We found that the Golgi proteins B3GALNT1, MAN1A1, FUT2, and MGAT4C represented a protein profile that may be suitable to monitor cellular depletion during decellularization processes, however the Golgi protein B3GNT5 was not fully depleted in our experiments potentially due to secondary interactions. Golgi proteins and the extent to which depletion was observed are listed in Table 2.

Table 2. Proteomic analysis of Golgi protein depletion by decellularization.

\begin{tabular}{ccc}
\hline Golgi Proteins & \% Depletion & Gene Symbol \\
\hline UDP-GalNAc:beta-1,3-N-acetylgalactosaminyltransferase 1 & 100 & B3GALNT1 \\
Mannosyl-oligosaccharide 1,2-alpha-mannosidase IA & 100 & MAN1A1 \\
Galactoside 2-alpha-L-fucosyltransferase 2 & 100 & FUT2 \\
Alpha-1,3-mannosyl-glycoprotein & 100 & MGAT4C \\
4-beta-N-acetylglucosaminyltransferase C & 66 & B3GNT5 \\
\hline
\end{tabular}

We investigated mitochondrial proteins to determine a protein profile of mitochondrial biomarkers that may serve as a reference set to provide more reliable indicators of decellularization. We measured the protein content of 29 mitochondrial proteins and found that 19 of these (ACO2, AKAP10, GOT2, CPT1B, CYP11A1, ATC4D, CYBB, COX17, CYP11B1, GPAM, GATM, MUT, RHOT2, UCP2, UCP3, MT-ND5, SDHA, CUCLG1, and VARS2) were efficiently depleted through the decellularization process. In contrast, some mitochondrial proteins were detected after the decellularization process, indicating that they may not be reliable indicators of decellularization. Mitochondrial proteins and their extent of depletion are listed in Table 3. 
Table 3. Mitochondrial proteins depleted during decellularization.

\begin{tabular}{|c|c|c|}
\hline Mitochondrial Proteins & \% Depletion & Gene Symbol \\
\hline Aconitate hydratase, mitochondrial & 100 & $\mathrm{ACO} 2$ \\
\hline A-kinase anchor protein 10, mitochondrial & 100 & AKAP10 \\
\hline Aspartate aminotransferase, mitochondrial & 100 & GOT2 \\
\hline Carnitine O-palmitoyltransferase 1, muscle isoform & 100 & СРT1B \\
\hline Cholesterol side-chain cleavage enzyme, mitochondrial & 100 & CYP11A1 \\
\hline Cysteine protease ATG4D & 100 & ATG4D \\
\hline Cytochrome b-245 heavy chain & 100 & CYBB \\
\hline Cytochrome c oxidase copper chaperone & 100 & COX17 \\
\hline Cytochrome P450 11B1, mitochondrial & 100 & CYP11B1 \\
\hline Glycerol-3-phosphate acyltransferase 1, mitochondrial & 100 & GPAM \\
\hline Glycine amidinotransferase, mitochondrial & 100 & GATM \\
\hline Methylmalonyl-CoA mutase, mitochondrial & 100 & MUT \\
\hline Mitochondrial Rho GTPase 2 & 100 & RHOT2 \\
\hline Mitochondrial uncoupling protein 2 & 100 & $\mathrm{UCP} 2$ \\
\hline Mitochondrial uncoupling protein 3 & 100 & UCP3 \\
\hline NADH-ubiquinone oxidoreductase chain 5 & 100 & MT-ND5 \\
\hline Succinate dehydrogenase [ubiquinone] flavoprotein subunit, mitochondrial & 100 & SDHA \\
\hline Succinate-CoA ligase [ADP/GDP-forming] subunit alpha, mitochondrial & 100 & SUCLG1 \\
\hline Valine-tRNA ligase, mitochondrial & 100 & VARS2 \\
\hline Amine oxidase [flavin-containing] B & 91 & MAOB \\
\hline Mitochondria-eating protein & 91 & SPATA18 \\
\hline Nicotinamide phosphoribosyltransferase & 91 & NAMPT \\
\hline Hexokinase-2 OS=Sus scrofa & 87 & HK2 \\
\hline Kynurenine 3-monooxygenase & 85 & $\mathrm{KMO}$ \\
\hline NADP-dependent malic enzyme & 83 & ME1 \\
\hline Cytochrome P450 3A29 & 78 & CYP3A29 \\
\hline Glyceraldehyde-3-phosphate dehydrogenase & 66 & GAPDH \\
\hline Hydroxymethylglutaryl-CoA synthase, mitochondrial & 66 & HMGCS2 \\
\hline Creatine kinase U-type, mitochondrial & 55 & CKMT1 \\
\hline
\end{tabular}

We investigated endoplasmic reticulum proteins by mass spectrometry before and after decellularization and found that a protein profile comprising 16 prevalent endoplasmic reticulum proteins may be considered as reliable biomarkers for decellularization processes. These include RPS13, RPS3, CYP8B1, RPL14, RPL6, CRYBB1, RPN2, HSPA5, FOLH1, HSPA1A, HSPA1B, HSPA1L, HMOX1, GANAB, ATP2A2, and VCP. Other endoplasmic reticulum proteins detected by mass spectrometry were not as efficiently removed from the tissue by the decellularization process and may indicate non-specific interactions that would render these proteins unreliable as indicators of decellularization. Endoplasmic reticulum proteins and the extent to which they were depleted during the decellularization process are listed in Appendix A, Table A1.

We investigated 65 membrane proteins to analyze the extent to which they were depleted during the decellularization process and found 38 that were reliably serve as indicators of decellularization. The biomarker profile of membrane proteins include ARF6, ALOX15, CAPN1, CXCR4, CYSLTR2, DSG1, EDNRA, GJA1, RABGGTA, GGT1, GHR, GNAQ, ITGB1, IFNAR1, IL4R, IL6R, LDLR, KIT, STEAP1, NTRK3, PTH1R, PDZD11, ATP2B1, PECAM1, PCDH11X, RAMP1, SAG, SIGLEC1, SLA-DQCA, SLA-DQCB, SLADQDB, KCNN3, SLC5A1, SLC22A6, SLC22A7, TPO, TLR9, and TGFBR3. Membrane protein biomarkers that may serve as suitable indicators of cellular depletion are listed in Appendix A, Table A2.

Analysis of cytosolic proteins showed that decellularization depleted the samples of these proteins as well. As shown in Appendix A, Table A3, we identified 40 cytosolic proteins that were depleted to a level exceeding $78 \%$. These profiles may be useful to others that desire to track the efficiency of the decellularization process.

We utilized mass spectrometry to characterize the composition of the scaffold resulting from our process. We quantified extracellular matrix proteins before and after decellu- 
larization. As expected, we found that many of the noncollagenous extracellular matrix proteins were significantly depleted during the process, as shown in Table 4. However, collagens were retained within the scaffold, as shown in Figure 6.

Table 4. Noncollagenous extracellular matrix proteins after decellularization.

\begin{tabular}{ccc}
\hline Extracellular Matrix Noncollagenous Proteins & \% Depleted & Gene Symbol \\
\hline Fibromodulin & 100 & FMOD \\
Dystroglycan & 100 & DAG1 \\
Fibrillin-1 & 100 & FBN1 \\
Aggrecan core protein & 100 & ACAN \\
Decorin & 100 & DCN \\
Lactadherin & 98 & MFGE8 \\
Hyaluronan and proteoglycan link protein 1 & 90 & HAPLN1 \\
Tenascin & 70 & TNC \\
Biglycan & 57 & BGN \\
\hline
\end{tabular}

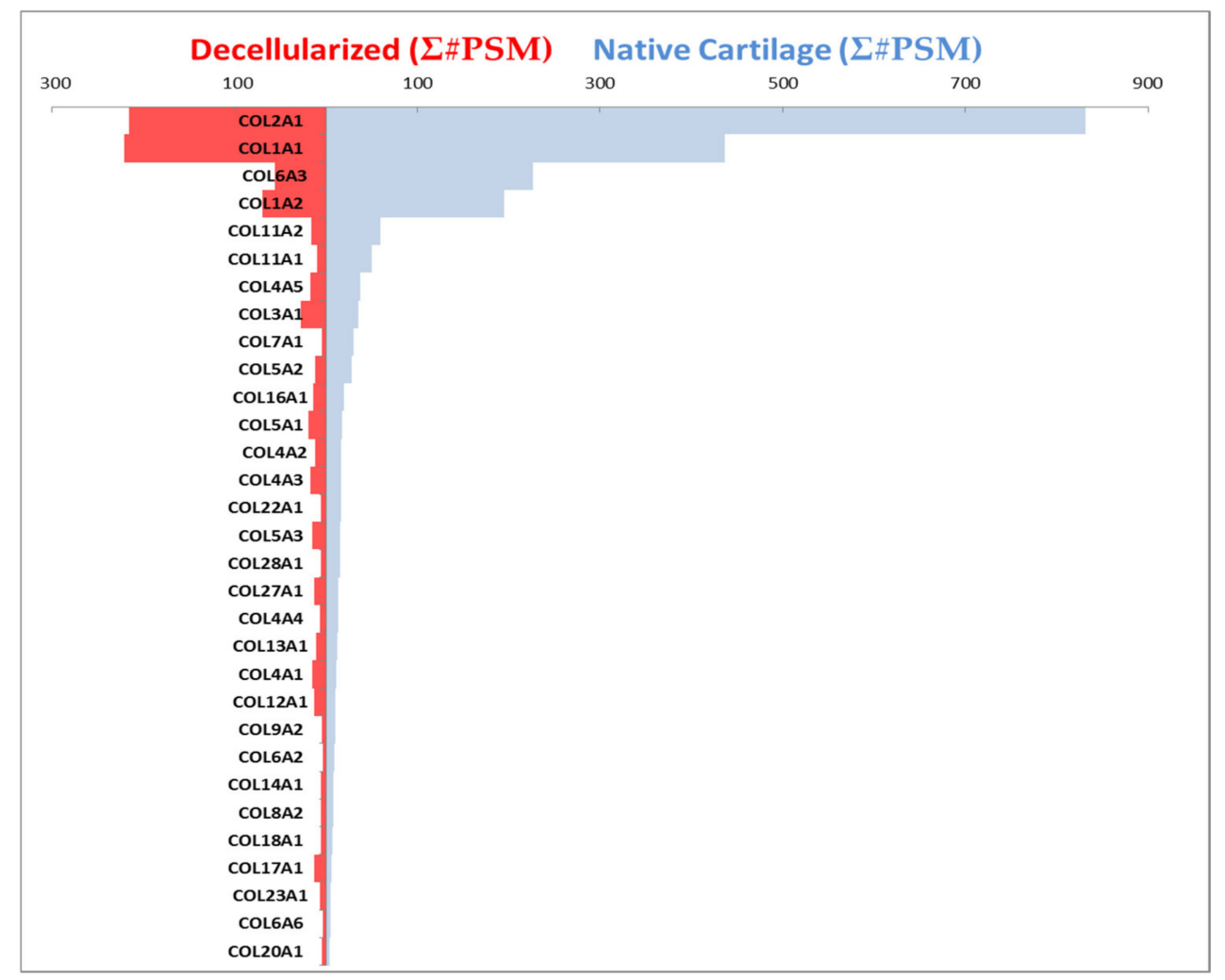

Figure 6. Collagenous composition of the decellularized scaffold. Blue bars show the collagens present in cartilage prior to the decellularization process, and red bars show composition of the scaffold after the decellularization process. The length of the bars to the left and right corresponds to abundance of the specific collagens. Collagen alpha chains are listed in the order of decreasing prevalence within native cartilage. The resulting decellularized scaffold (red) contained COL2A1, COL1A1, COL6A3, COL1A2, COL11A2, COL11A1, COL4A5, COL3A1, COL5A2, COL16A1, COL5A1, COL4A2, COL4A3, COL5A3, COL27A1, COL13A1, COL4A1, COL12A1, and COL17A1. Minor contributions of COL7A1, COL22A1, COL28A1, COL4A4, COL9A2, COL6A2, COL14A1, COL8A2, COL18A1, COL23A1, COL6A6, and COL20A1 were detected after decellularization. Horizontal axes values represent the sum of peptide spectrum matches (PSM), the total number of identified peptides for each collagen as an indication of quantity.

Collagen alpha chains were analyzed before and after decellularization to assess collagenous composition of the resulting decellularized scaffold. The collagen alpha chains 
were detected in native cartilage by mass spectrometry prior to decellularization. After the decellularization process, nine of these were no longer detectable as shown in Figure 6. Blue horizontal bars indicate the composition of cartilage before the decellularization process, and red bars show the composition of the scaffold after the decellularization process. The resulting decellularized scaffold (red) contained COL2A1, COL1A1, COL6A3, COL1A2, COL11A2, COL11A1, COL4A5, COL3A1, COL5A2, COL16A1, COL5A1, COL4A2, COL4A3, COL5A3, COL27A1, COL13A1, COL4A1, COL12A1, and COL17A1. Minor contributions by COL7A1, COL22A1, COL28A1, COL4A4, COL9A2, COL6A2, COL14A1, COL8A2, COL18A1, COL23A1, COL6A6, and COL20A1 were detected in the final decellularized cartilage scaffold (Figure 6). The final decellularized cartilage scaffold did not contain detectable levels of COL5A1, COL10A1, COL8A1, COL21A1, COL25A1, COL9A1, COL6A5, COL15A1, and COL26A1.

To test the biocompatibility of our scaffold, we seeded C28/I2 human chondrocyte cells onto the scaffold and maintained these constructs in culture. After one week, we observed cells associated with the surface of our scaffold, as shown in Figure 7. Scanning electron micrographs showed that the cells were maintained on the surface of the scaffold. Cellular clusters were observed after 8 months as shown in Figure $7 \mathrm{~b}$.

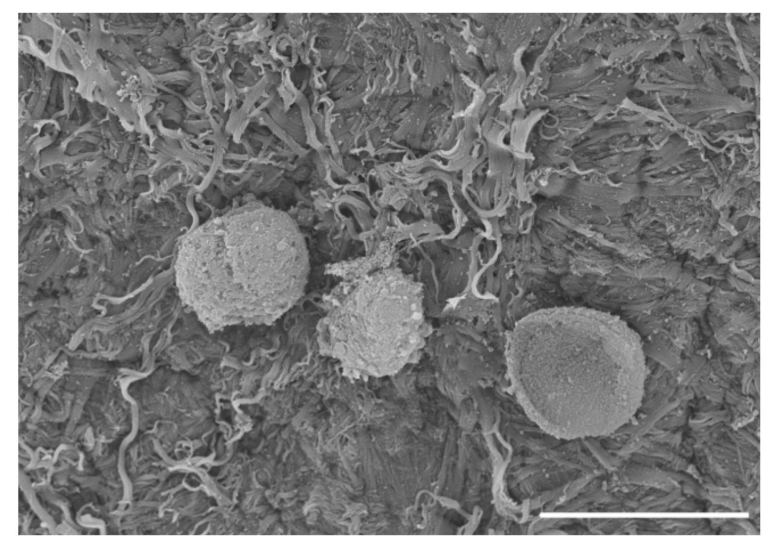

(a)

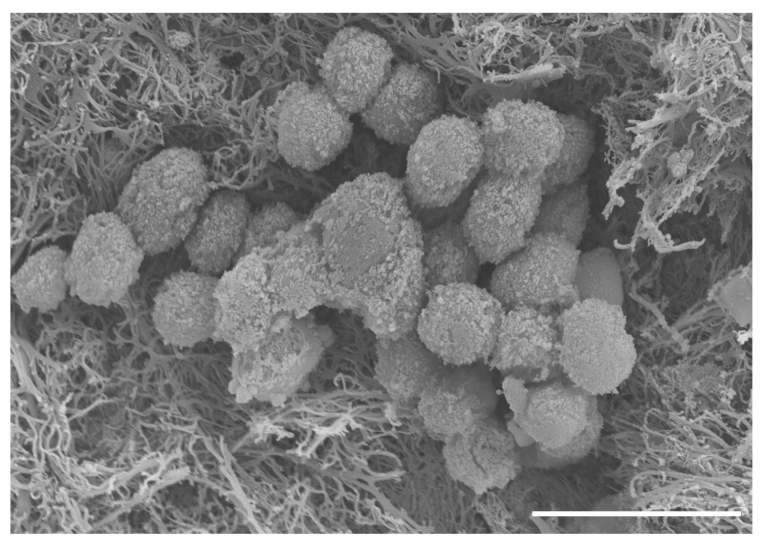

(b)

Figure 7. Scanning electron micrographs of C28/I2 chondrocyte cells on decellularized scaffold. (a) Cells attached to scaffold after 1 week in culture. (b) Cells on scaffold after 8 months in culture. Scale bar $=20 \mu \mathrm{m}$.

Cellular response was evaluated using quantitative real-time PCR to monitor the expression of genes related to chondrogenic differentiation. Five candidate housekeeping genes were compared for all experimental conditions used in this study to identify those that remain constant and may therefore serve as appropriate housekeeping genes. GAPDH and HPRT1 were selected as the housekeeping gene for normalization in these experiments based on comparison to three other candidate housekeeping genes and were found to be stably expressed independent of experimental conditions based on minimal variance as shown in Figure 8.

The expression levels of genes related to chondrogenic differentiation were determined relative to housekeeping genes and these relative abundance values were reported as mean plus/minus standard deviation. Correlation analysis of gene expression was carried out to compare gene expression over time on conventional tissue culture plastic (Figure 9a) comparing day 7 to day 0 in culture. Correlation analysis was also carried out to compare gene expression of cells grown on the scaffold to the gene expression levels on tissue culture plastic after 7 days in culture (Figure $9 \mathrm{~b}$ ). The diagonal line indicates the trend expected if there is no change between the cartilage scaffold and plastic. Data points above the line reflect genes expressed at higher levels on the cartilage scaffold compared to plastic (Figure $9 \mathrm{~b}$ ). Data points below the diagonal line indicate genes that were expressed at 
higher levels on tissue culture plastic compared to the cartilage scaffold. Data points that fall on the line were not changed based on culture conditions.

\begin{tabular}{|c|c|c|c|c|c|}
\hline \multicolumn{2}{|l|}{ АСТВ } & & & & \\
\hline B2M & 87.49 & & & & \\
\hline GAPDH & 140.54 & 10.77 & & & \\
\hline HPRT1 & 135.44 & 9.01 & 0.11 & & \\
\hline \multirow[t]{2}{*}{ RPLPO } & 125.96 & 7.34 & 1.49 & 0.91 & \\
\hline & ACTB & B2M & GAPDH & HPRT1 & RPLPO \\
\hline
\end{tabular}

Figure 8. Analysis of variance of difference to determine most suitable housekeeping genes. Candidate housekeeping genes were considered in a pairwise fashion to determine which ones were the most consistently expressed independent of experimental condition within this study. GAPDH and HPRT1 displayed the minimum variance of difference over all experimental conditions and timepoints.

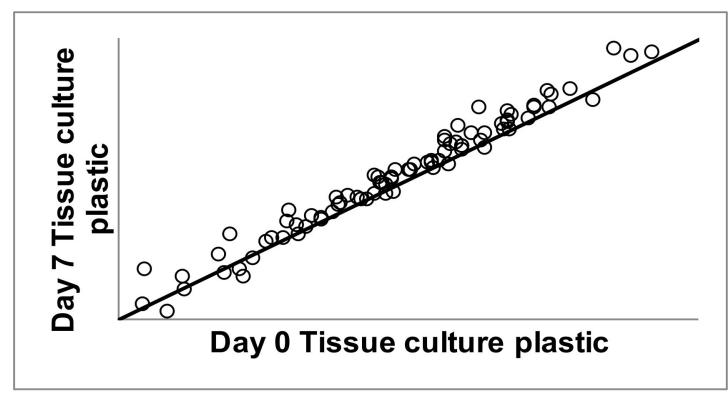

(a)

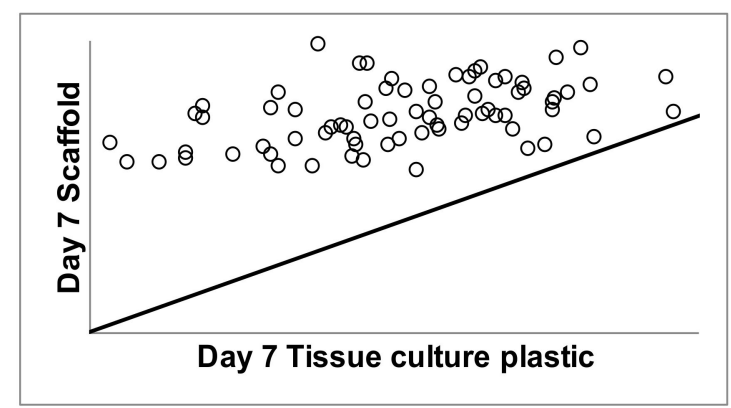

(b)

Figure 9. Correlation analysis of gene expression during growth on tissue culture plastic and cartilage scaffold. C28/I2 cells were grown under conventional conditions on tissue culture plastic for one week (a) and compared to cells grown on cartilage scaffold for 7 days $(\mathbf{b})$. The diagonal line in $(\mathbf{a}, \mathbf{b})$ indicates the trend expected if there was no change between conditions; day 0 versus day 7 on tissue culture plastic in (a) and day 7 on tissue culture plastic versus day 7 on cartilage scaffold in (b). Data points above the line reflect genes expressed at higher levels on the cartilage scaffold compared to plastic. Data points below the line indicate genes that were expressed at higher levels on plastic compared to the cartilage scaffold. Data points that fall on the line were not changed.

A total of 77 genes were analyzed during C28/I2 chondrocyte cell culture and differentiation for 7 days. We identified 52 genes that were upregulated from day 0 to day 7 on standard tissue culture plastic and therefore serve as indicators of chondrocyte phenotype. Of those 52 genes, 33 genes also showed an increase in expression when cells were cultured on decellularized 3D porcine scaffold. A total of 19 genes were upregulated in cells maintained on tissue culture plastics but were not upregulated significantly during the same time period by cells cultured on decellularized porcine cartilage scaffold. A total of 25 genes were upregulated in cells grown on decellularized scaffold that were not observed to be upregulated on tissue culture plastic under standard 2D culture conditions and these are summarized in Table 5 and Figure 10. 
Table 5. Genes unique to scaffold compared to growth on tissue culture plastic.

\begin{tabular}{|c|c|c|c|}
\hline Gene Symbol & Name & Function & Reference \\
\hline CLEC3B & $\begin{array}{l}\text { C-type lectin domain family } 3, \\
\text { member B }\end{array}$ & $\begin{array}{l}\text { Encodes tetranectin. Cellular response to } \\
\text { transforming growth factor stimulus. }\end{array}$ & $\begin{array}{l}\text { Steinberg } 2017 \text { [24] } \\
\text { Valdes } 2011 \text { [25] } \\
\text { Karlsson } 2010 \text { [26] } \\
\text { Mazzoni } 2020 \text { [27] }\end{array}$ \\
\hline COL12A1 & Collagen, type XII, alpha 1 & $\begin{array}{l}\text { Encodes the alpha chain of type XII collagen. } \\
\text { Modifies the interactions between collagen } \\
\text { fibrils and the surrounding matrix. A } \\
\text { component of cartilage ECM. }\end{array}$ & $\begin{array}{c}\text { Johnson } 2015 \text { [28] } \\
\text { Zeggini } 2012 \text { [29] } \\
\text { Manon-Jensen 2016 [30] } \\
\text { Luo 2017 [31] } \\
\text { Agarwal 2012 [32] }\end{array}$ \\
\hline COL15A1 & Collagen, type XV, alpha 1 & $\begin{array}{l}\text { Encodes the alpha chain of type XV collagen. } \\
\text { Strongest expression in basement membrane } \\
\text { zones; may function to adhere basement } \\
\text { membranes to underlying connective tissue. }\end{array}$ & $\begin{array}{l}\text { Karlsson } 2010[26] \\
\text { Zhou } 2010[33] \\
\text { Valdes } 2011[25]\end{array}$ \\
\hline CTGF & Connective tissue growth factor & $\begin{array}{l}\text { Modulates signaling pathways leading to cell } \\
\text { adhesion and migration, along with ECM } \\
\text { deposition and remodeling, which together lead } \\
\text { to tissue remodeling. }\end{array}$ & $\begin{array}{l}\text { Tang } 2018[34] \\
\text { Ivkovic } 2003 \text { [35] } \\
\text { Shi-Wen } 2008 \text { [36] } \\
\text { Lipson } 2012[37]\end{array}$ \\
\hline ECM1 & Extracellular matrix protein 1 & $\begin{array}{l}\text { Inhibits chondrocyte hypertrophy, matrix } \\
\text { mineralization, and endochondral } \\
\text { bone formation. }\end{array}$ & $\begin{array}{l}\text { Kong } 2016[38] \\
\text { Mongiat } 2003[39] \\
\text { Frahs } 2019[40] \\
\text { Kong } 2010[41]\end{array}$ \\
\hline ICAM1 & Intercellular adhesion molecule 1 & Encodes cell surface glycoprotein. & $\begin{array}{c}\text { Yatabe 2009 [42] } \\
\text { Gromova } 2018 \text { [43] } \\
\text { Rangkasenee } 2013 \text { [44] }\end{array}$ \\
\hline ITGA3 & $\begin{array}{c}\text { Integrin, alpha } 3 \text { (antigen CD49C, } \\
\text { alpha } 3 \text { subunit of } \\
\text { VLA-3 receptor) }\end{array}$ & Involved in cell adhesion and collagen binding. & Zhang 2019 [45] \\
\hline ITGA4 & $\begin{array}{l}\text { Integrin, alpha } 4 \text { (antigen } \\
\text { CD49D, alpha } 4 \text { subunit of } \\
\text { VLA-4 receptor) }\end{array}$ & $\begin{array}{l}\text { Functions in cell surface adhesion and signaling, } \\
\text { ECM receptor interaction. }\end{array}$ & $\begin{array}{l}\text { Djouad } 2007 \text { [46] } \\
\text { Weeks } 2012 \text { [47] } \\
\text { Zhu } 2017 \text { [48] }\end{array}$ \\
\hline ITGA6 & Integrin, alpha 6 & $\begin{array}{l}\text { Functions in cell surface adhesion } \\
\text { and signaling. }\end{array}$ & $\begin{array}{c}\text { Tu } 2020[49] \\
\text { LaPointe } 2013[50]\end{array}$ \\
\hline LAMA1 & Laminin, alpha 1 & $\begin{array}{l}\text { Major component of the basement membrane. } \\
\text { Associated with cell adhesion, differentiation, } \\
\text { migration, and signaling. }\end{array}$ & $\begin{array}{c}\text { Zhang } 2019 \text { [45] } \\
\text { Wang } 2019 \text { [51] } \\
\text { Soki } 2018 \text { [52] } \\
\text { Adapala } 2016 \text { [53] } \\
\text { Grogan } 2013 \text { [54] } \\
\text { Mann } 2019 \text { [55] }\end{array}$ \\
\hline MMP10 & $\begin{array}{l}\text { Matrix metallopeptidase } 10 \\
\quad(\text { stromelysin } 2)\end{array}$ & $\begin{array}{l}\text { Involved in the breakdown of extracellular } \\
\text { matrix in normal physiological processes, such } \\
\text { as tissue remodeling. }\end{array}$ & $\begin{array}{l}\text { Dehne } 2010 \text { [56] } \\
\text { Gohring } 2010 \text { [57] }\end{array}$ \\
\hline MMP12 & Matrix metallopeptidase 12 & $\begin{array}{l}\text { Involved in the breakdown of extracellular } \\
\text { matrix in normal physiological processes, such } \\
\text { as tissue remodeling. }\end{array}$ & $\begin{array}{l}\text { Dehne } 2010 \text { [56] } \\
\text { Lv } 2016 \text { [58] }\end{array}$ \\
\hline MMP9 & $\begin{array}{l}\text { Matrix metallopeptidase } 9 \\
\text { (gelatinase B, } 92 \mathrm{kDa} \text { gelatinase, } \\
92 \mathrm{kDa} \text { type IV collagenase) }\end{array}$ & $\begin{array}{l}\text { Involved in the breakdown of extracellular } \\
\text { matrix in normal physiological processes, such } \\
\text { as tissue remodeling. }\end{array}$ & $\begin{array}{l}\text { Challa } 2010[59] \\
\text { Yang } 2015[60] \\
\text { Miao } 2004[61]\end{array}$ \\
\hline SELP & $\begin{array}{l}\text { Selectin P (granule membrane } \\
\text { protein } 140 \mathrm{kDa} \text {, antigen CD62) }\end{array}$ & $\begin{array}{l}\text { This protein redistributes to the plasma } \\
\text { membrane during platelet activation } \\
\text { and degranulation. }\end{array}$ & $\begin{array}{l}\text { Weeks } 2012[47] \\
\text { Gari } 2016[62] \\
\text { Rouillard } 2016[63] \\
\text { Bonn } 2010[64]\end{array}$ \\
\hline
\end{tabular}


Table 5. Cont.

\begin{tabular}{|c|c|c|c|}
\hline Gene Symbol & Name & Function & Reference \\
\hline THBS3 & Thrombospondin 3 & $\begin{array}{l}\text { Mediates cell-to-cell and cell-to-matrix } \\
\text { interactions. Found in developing cartilage. }\end{array}$ & $\begin{array}{c}\text { Vos } 1992 \text { [65] } \\
\text { Adolph } 1995 \text { [66] } \\
\text { Djouad } 2007 \text { [46] } \\
\text { Posey } 2008 \text { [67] } \\
\text { Hankenson } 2005 \text { [68] }\end{array}$ \\
\hline VCAN & Versican & $\begin{array}{c}\text { Major component of the ECM; involved in cell } \\
\text { adhesion and proliferation } \\
\text { during chondrogenesis. }\end{array}$ & $\begin{array}{l}\text { Kamiya } 2006[69] \\
\text { Choocheep } 2010[70] \\
\text { Sztrolovics } 2002[71]\end{array}$ \\
\hline VTN & Vitronectin & $\begin{array}{l}\text { ECM markers that promote cell adhesion } \\
\text { and spreading. }\end{array}$ & $\begin{array}{l}\text { Luo } 2017[72] \\
\text { Vieira } 2015[73] \\
\text { Pei } 2013[74]\end{array}$ \\
\hline
\end{tabular}

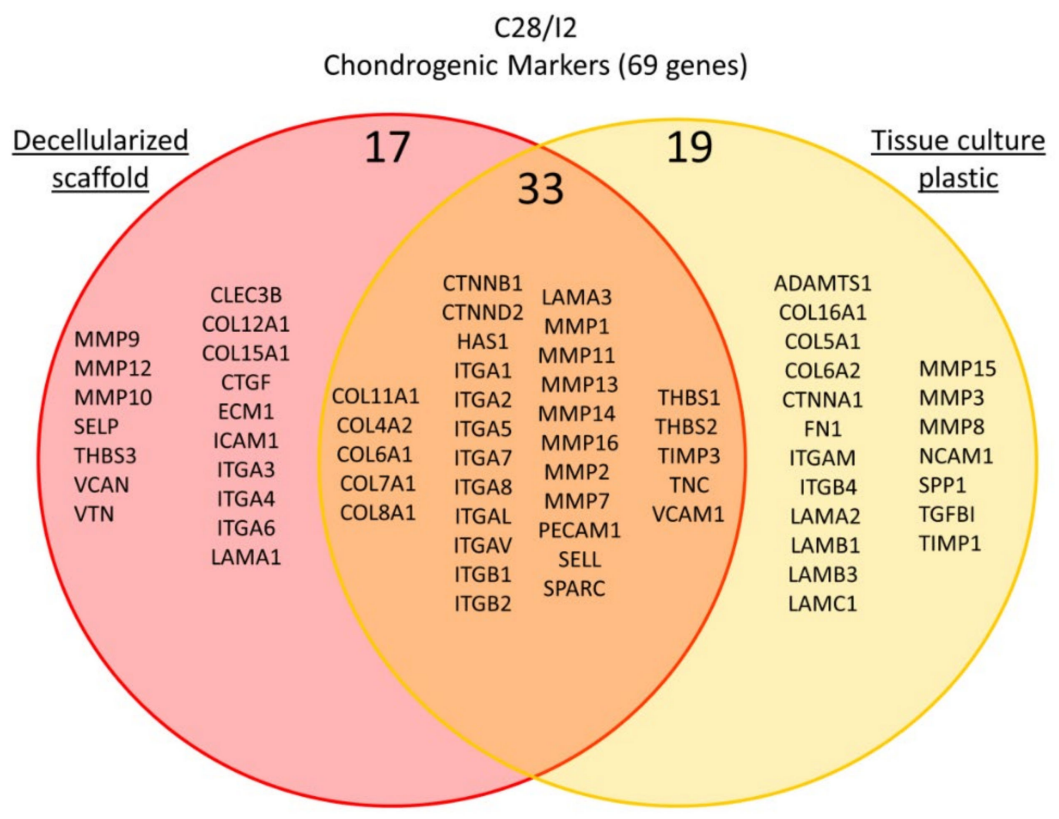

Figure 10. Gene expression of markers in C28/I2 cells. Gene expression for extracellular matrix, cell adhesion molecules, and cell-cell attachment proteins was measured by quantitative real-time PCR. The venn diagram clusters genes with respect to upregulation in cells grown on conventional tissue culture plastic shown in yellow, in cells grown on the decellularized cartilage scaffold shown in pink. Genes that were upregulated under both conditions are shown in the orange overlap region of the Venn diagram.

\section{Discussion and Conclusions}

In this study, we used decellularization to create an extracellular matrix scaffold that supports chondrocyte cell attachment and growth. We evaluated the decellularization process histologically and molecularly. Our conclusions identify new and novel biomarker profiles that may aid future cartilage decellularization efforts. The resulting scaffold was characterized using scanning electron microscopy, fluorescence microscopy, and proteomics. Cellular response to the decellularized scaffold was evaluated by quantitative real-time PCR and mass spectrometry for gene expression and proteomic analysis to analyze collagen content. Our approach demonstrated effective decellularization of a porcine cartilage scaffold by monitoring DNA content before and after decellularization.

Osteoarthritis is one of the leading causes of disability worldwide [1-4]. Many studies have investigated the use of various scaffolds as provisional chondro-inductive matrices $[1,2,5]$. In addition to biocompatibility, criteria for tissue engineering composites 
include (1) resorbability, (2) the ability to resist mechanical stresses, and (3) clinical relevance. Scaffolds must support cell differentiation and maintenance of a mature cartilage phenotype. However, there is no standard decellularization method to date. Previously published approaches include chemical, physical, or combinative methods [6-8,19].

The ultimate goal of decellularization is to remove all native genetic information and cellular components from the ECM. Surfactants, acid and bases, and enzymes make up the chemical and enzymatic portion of the process. Mechanical agents are also under study to determine the effectiveness for decellularization of a tissue or organ. These agents typically work by lysing cells through disrupting the phospholipid bilayer of the cell membrane. Ionic surfactants are widely used to remove cells and genetic material $[19,20]$. Treatments should be applied with continuous shaking [75,76]. Sodium dodecyl sulfate (SDS) currently meets the standard requirements of complete cell removal and elimination of at least $90 \%$ DNA [23]. SDS has been shown to damage structural properties if used at high concentration for long durations $[6,7,20,21,23]$. A comparison of five different decellularization treatments showed that several methods resulted in a significant reduction of DNA. Treatment with 2\% SDS for eight hours resulted in the greatest decrease of DNA; with only minor decreased collagen content $[6,7,20]$.

Some conflicting information exists in the literature regarding the duration of $1 \%$ SDS washes. The time to reach desired decellularization results range from $24 \mathrm{~h}$ to seven days $[23,75,77]$. The reported results indicate that the number of cells could be significantly reduced from engineered constructs. Higher or lower levels of DNA are most likely related to the thickness of tissue and the concentration and duration of specific detergents $[20,23,77]$.

Only a few studies have explored decellularization of whole cartilage scaffolds for joint regeneration $[23,75]$. In this study, we used ethanol to defat samples and guanidine hydrochloride and sodium acetate to denature and remove noncollagenous components from cartilage dissected from the ear. Guanidine hydrochloride and sodium acetate have been shown to be effective for denature and remove noncollagenous components [75].

In this study, sodium hydroxide $(\mathrm{NaOH})$ was used to inactivate cellular proteins and pathogens and denature DNA and RNA. Previous studies have shown that $\mathrm{NaOH}$ is an effective means of inactivating cellular proteins and pathogens and denaturating DNA and RNA. NaOH treatment removes cells and helps increase the porosity of the tissue [23,75].

Our study included the use of freeze-thaw cycles to help increase the porosity by forming more pores Freeze-thaw cycles have been shown to result in the formation of pores after ice crystal formation in addition to contributing to the disruption of resident chondrocytes. These cycles are often conducted in phosphate-buffered saline (PBS) solution to maintain physiological $\mathrm{pH}$ and osmolality, which additionally helps remove the residual reagents $[7,19,20,23,76-79]$.

In this study, DNase and RNase treatments were used to remove DNA and RNA. DNase and RNase may require as many as three cycles to accomplish complete depletion of native genetic material [7,19,20,23,76-79]. Removal of $99 \%$ of genomic material was observed after a six-day wash cycle in our studies [23]. To quantify the DNA present in cartilage samples before and after decellularization, we used a DNA extraction process [21,79]. The DNA content of the sample was also assessed using Hoechst stain [21,23]. We concluded that the decellularization wash cycles successfully resulted in decellularizing the porcine cartilage scaffold. Traditionally, laboratories have monitored DNA content to determine if cells have been removed since all cells contain DNA. However, DNA may be present even when cells no longer exist due to potential interaction between the matrix and the DNA. Therefore, mass spectrometry was used to measure the removal of cellular proteins including those from the nucleus, mitochondria and Golgi, cytosol, rough endoplasmic reticulum, and plasma membrane. These additional measures more thoroughly demonstrated that the cells were removed at least to a level below the threshold of detection. In this study, lyophilization was used to help with cell disruption and removal of cellular components $[78,79]$. All samples were sterilized before using for cell culture. 
To our knowledge, this study represents the first demonstration of biomarker analysis for decellularization of porcine ear for cartilage regeneration. Additionally, PCR was used to quantify mRNA expression of key chondrogenic differentiation markers expressed by cells after seeding on the scaffold. Chondrogenic marker genes were analyzed for significant changes between control cells grown on tissue culture plastic and those grown under conditions provided by the decellularized scaffold [76]. The cells expressed genes, as shown in PCR and proteomic data. There have been limited proteomic studies of cartilage, which may be because of the difficulty in determining the amount of protein contribution by the cells relative to the total protein contributed by the ECM [80]. The collagen fibers of the ECM were maintained during the process. Characterization of the scaffold showed that thirty-nine collagen alpha chains were detected in the cartilage prior to decellularization by mass spectrometry. After the decellularization process, nine of these were decreased below the limit of detection. While most of the collagens were maintained throughout the decellularization process, nine were depleted to the extent that they were no longer detectable by mass spectrometry.

SEM was used to visualize the surface topology of the decellularized scaffold $[19,23,75,81]$. The scaffold was shown to be less smooth and displayed exposed collagenous fibrillar networks after decellularization in SEM and more porous by histology when compared to the original material. SEM images showed cells could attach and proliferate on the surface of the scaffold.

Previous work has not fully analyzed what is left behind after decellularization. Future work should be carried out to better understand the material remaining after decellularization as it is important when evaluating laboratory-generated cartilage for patient-specific biocompatibility. This study is novel because it generates new knowledge by analyzing the protein profile of the decellularized tissue and contributes biomarkers other than well-established COL2A1 and ACAN. It provides an improved approach to monitoring decellularization and insight into acceptable markers for decellularization by looking at the protein profile of markers instead of just one or two proteins. The use of patient-specific MSCs or pre-chondrocytes will advance this line of research. A limitation of this study was that it focused on short-term changes. The scaffolds grown up to eight months showed an increase in cellular adhesion and proliferation. Future experiments in cell culture should extend duration as well as monitor protein synthesis and accumulation over time by proteomics, since protein expression does not always follow RNA expression. In this case, we will identify newly synthesized human proteins based on the number of unique peptides for human proteins for quantification. Additionally, it will be important to test biocompatibility. Another limitation may be the dense nature of native cartilage which restricts cell migration into the matrix. To address this limitation, future studies will include introduction of pores to allow penetration of cells into the center of the scaffold. An alternative approach that will be considered for future studies is devitalized cartilage to deliver higher concentrations of endogenous growth factors that may aid in cellular differentiation. In our procedure, soluble growth factors were removed due to the harsh conditions used.

Overall, this novel research shows promise that laboratory-generated cartilage may be a future alternative treatment option for individuals suffering from OA. Cartilage discs can be made to fit specific cartilage lesions. This approach aims to restore the patient's natural anatomy and prevent the need of a joint replacement. Using decellularization to create biomaterials can generate biocompatible scaffolds. Patient-specific chondrocytes may promote formation of a tissue that has superior compatibility for replacement or healing of damaged tissue.

\section{Materials and Methods}

\subsection{Materials}

Four pig ears were acquired from Wakefield Meats in Melba, Idaho. The pigs were estimated to be one year of age and of adult size. 


\subsection{Methods}

The pig ears were shaved to remove hair, and a scalpel was used to remove remaining skin without damaging the underlying cartilage layer. Samples were placed in a $0.5 \mathrm{M}$ $\mathrm{NaOH}$ bath overnight.

Tissue was transferred to a $1.0 \mathrm{M} \mathrm{NaOH}$ solution for three hours followed by transfer to a $70 \%$ ethanol solution and incubated at $40{ }^{\circ} \mathrm{C}$ with heating for three hours.

Pig ear cartilage was converted into $8 \mathrm{~mm}$ circular discs using a tissue punch. Twenty $8 \mathrm{~mm}$ punches were frozen to be used for characterization of the cartilage-derived scaffold before decellularization.

\subsubsection{Decellularization}

Three hundred and twenty $8 \mathrm{~mm}$ cartilage discs with a thickness of $1.08 \mathrm{~mm}$ underwent a decellularization cycle. Then, $1 \mathrm{M}$ guanidine hydrochloride and $0.05 \mathrm{M}$ sodium acetate were used to incubate with agitation at $4{ }^{\circ} \mathrm{C}$ for $96 \mathrm{~h}$ as described in Schwarz et al. 2012 [75]. Samples were subjected to three freeze-thaw cycles in 1\% PBS [19,23,76-79]. Samples were washed in $10 \mathrm{mM}$ Tris hydroxymethyl aminomethane (Tris)- $\mathrm{HCl}, 2 \mathrm{mM}$ ethylenediaminetetraacetic acid (EDTA), $5 \mathrm{mM} \mathrm{MgCl} 2,100 \mathrm{mM}$ dithiothreitol (DTT), $1 \%$ SDS, and $1 \%$ Triton-X100, $\mathrm{pH}$ of 8.0 , for $39 \mathrm{~h}$ with agitation at $22^{\circ} \mathrm{C}$, as described $[19,23,74,76,81]$. To remove HA and proteoglycans, the cartilage discs were incubated in PBS with $21 \mathrm{U} / \mathrm{mL}$ of hyaluronidase at $37^{\circ} \mathrm{C}$ for $24 \mathrm{~h}$ as described in Luo et al. 2016 [23]. Subsequently, the samples were treated with DNase and RNase for $24 \mathrm{~h}$ at $37^{\circ} \mathrm{C}$ to degrade DNA and RNA [19,23].

Residual cells were identified based on H\&E staining. SEM was performed on the nondecellularized and decellularized tissues at this intermediate step. A second series of washes was carried out to remove the residual cells. Samples underwent another freezethaw cycle in DI water and 2\% SDS with agitation. Samples were treated with DNase for $72 \mathrm{~h}$ at $37^{\circ} \mathrm{C}$ with agitation, and samples were analyzed by histology, Hoechst staining, and SEM.

A third series of decellularization washing cycles was carried out followed by lyophilization. DNA removal was confirmed by extraction and purification of total DNA using DNeasy Kit for purification of total DNA from animal tissue (Qiagen).

\subsubsection{Histology}

The cartilage samples were fixed in $4 \%$ paraformaldehyde (PFA) for $1 \mathrm{~h}$ and then stored in $35 \%$ ethanol at $4{ }^{\circ} \mathrm{C}$ and then dehydrated, cleared in Histoclear, and embedded in paraffin. The tissue block was sectioned to achieve both transverse and cross-section configuration on the slide and stained with H\&E and Hoechst stain. Hoechst stain $(1 \mu \mathrm{g} / \mathrm{mL})$ was placed on the sample for $5 \mathrm{~min}$, then rinsed 3 times with PBS. The samples were then imaged on a Zeiss Confocal LSM 510 Meta microscope.

\subsubsection{SEM Preparation and Imaging}

Cartilage discs were fixed in $2.5 \%$ glutaraldehyde and $1 \%$ osmium tetroxide in Nanopure water. After fixation, samples underwent dehydration with $50 \%, 70 \%, 90 \%$, and $100 \%$ ethanol. Critical point drying was performed for 10 cycles at $5{ }^{\circ} \mathrm{C}$ then heated to $35^{\circ} \mathrm{C}$. Samples were positioned onto an aluminum stub and sealed under vacuum. Gold sputtering was performed at 0.15 megabar (mbar) and 10 milliamp (mA) for 15 cycles of $60 \mathrm{~s}$ sputtering and $60 \mathrm{~s}$ of rest. Prepped samples were examined at an accelerating voltage of 15 kilovolts $(\mathrm{kV})$ using the secondary electron detector.

\subsubsection{PCR}

RNA from cells seeded on cartilage scaffold or from cells grown on conventional tissue culture plastic was extracted using TRIzol. Complementary DNA (cDNA) synthesis was carried out using the RT2 First Strand Kit (Qiagen) followed by qRT-PCR in a 96-well plate using a Roche LightCycler96 ${ }^{\circledR}$. The samples underwent one cycle for $10 \mathrm{~min}$ at 
$95^{\circ} \mathrm{C}$ and then 45 cycles of $15 \mathrm{~s}$ at $95{ }^{\circ} \mathrm{C}$ and $1 \mathrm{~min}$ of $60^{\circ} \mathrm{C}$. Analyzed genes included extracellular matrix proteins, matrix remodeling enzymes, and cell adhesion molecules. PCR primers were purchased from Qiagen (Cat. no. 330231 PAHS-013ZA). Relative gene expression levels, mean of three replicates plus/minus standard deviation, were expressed with respect to housekeeping genes determined empirically for this study.

\subsubsection{Protein Concentration Determination}

The total protein concentration of the homogenate for all samples was determined using Pierce ${ }^{\mathrm{TM}}$ BCA (Bicinchoninic Acid) Protein Assay Kit, Thermo Scientific ${ }^{\circledR}$.

\subsubsection{Mass Spectrometry and Proteomics}

Proteins from nondecellularized, decellularized, and recellularized scaffolds were homogenized and extracted using RIPA buffer (Millipore, Billerica, MA, USA) Twenty micrograms of total protein from each sample was digested with Trypsin/Lys C mix (Promega, Madison, WI, USA) following the manufacturer's instruction. Resulting peptide mixtures were chromatographically separated on a reverse-phase C18 column $(10 \mathrm{~cm} \times 75 \mu \mathrm{m}$, $3 \mu \mathrm{m}, 120 \AA$ ) and analyzed on a Velos Pro Dual-Pressure Linear Ion Trap mass spectrometer (Thermo Fisher Scientific).

Peptide spectral matching and porcine and human protein identification were achieved by database search using Sequest HT algorithms in a Proteome Discoverer 2.2 (Thermo Fisher Scientific). Raw spectrum data were searched against the UniProtKB/Swiss-Prot and TrEMBL porcine protein databases and Swiss-Prot human protein database (25 May 2019). The main search parameters included trypsin, maximum missed cleavage site of two, precursor mass tolerance of $1.5 \mathrm{Da}$, fragment mass tolerance of $0.8 \mathrm{Da}$, and variable modification of oxidation/hydroxylation of methionine, proline, and lysine (+15.995 Da). A decoy database search was performed to calculate a false discovery rate (FDR). Proteins containing one or more peptides with FDR $\leq 0.05$ were considered positively identified and reported. For all proteins, the total number of peptide spectral matches (PSMs) reported by the Protein Discoverer 2.2 was used for quantification. The mass spectrometry analysis used three samples at each condition and time point.

\subsubsection{Recellularization of Decellularized Scaffold}

Final decellularized cartilage scaffold was sterilized in $70 \%$ ethanol and rehydrated in $10 \%$ PBS for $24 \mathrm{~h}$ at $4{ }^{\circ} \mathrm{C}$ followed by incubation in Dulbecco's modified Eagle's medium (DMEM) with $10 \%$ fetal bovine serum (FBS) and 1\% penicillin-streptomycin).

Twenty-four-well plates were prepared with $300 \mu \mathrm{L}$ of agarose gel in the bottom of each well and sterilized cartilage scaffold discs were seeded with 500,000 C28/I2 cells each. Characterization took place at seven days for PCR analysis and one week and 8 months for SEM analysis.

\subsubsection{Statistical Analysis}

Selection of housekeeping genes for qRT-PCR was based on pairwise analysis of variance for differences between cycle threshold values for five candidate housekeeping genes from 15 samples within this study. Relative expression of genes of interest was analyzed relative to average values for GAPDH and HPRT1 and expressed as mean plus/minus standard deviation. Log-transformed gene expression data were subject to a paired T-test to determine if the differences in mean values for relative gene expression were statistically significant with $p<0.05$.

Author Contributions: Conceptualization, R.N.S. and J.T.O.; methodology, R.N.S., S.M.F., M.J.H., X.P., C.K.-P.; validation, R.N.S., A.F., S.M.F., X.P., C.K.-P.; writing-original draft preparation, R.N.S.; writing-review and editing, R.N.S., M.J.H. and J.T.O.; supervision, J.T.O.; funding acquisition, J.T.O. All authors have read and agreed to the published version of the manuscript. 
Funding: The project described was supported by Institutional Development Awards (IDeA) from the National Institute of General Medical Sciences of the National Institutes of Health under Grants \#P20GM103408 and \#P20GM109095. We also acknowledge support from the Biomolecular Research Center at Boise State with funding from the National Science Foundation, Grants \#0619793 and \#0923535; the MJ Murdock Charitable Trust; Duane and Lori Stueckle Endowed Chair, and the Idaho State Board of Education.

Institutional Review Board Statement: Not applicable.

Informed Consent Statement: Not applicable.

Data Availability Statement: The datasets used and/or analyzed during the current study are available from the corresponding author upon request.

Acknowledgments: Authors acknowledge the administrative and technical support of Sara Rostron, Tracy Yarnell, Amy Moll, William Bourland, and David Estrada.

Conflicts of Interest: The authors declare no conflict of interest. The funders had no role in the design of the study; in the collection, analyses, or interpretation of data; in the writing of the manuscript; or in the decision to publish the results.

\section{Appendix A}

Table A1. Endoplasmic reticulum proteins depleted during decellularization.

\begin{tabular}{|c|c|c|}
\hline Endoplasmic Reticulum & $\%$ Depletion & Gene Symbol \\
\hline $40 S$ ribosomal protein $\mathrm{S} 13$ & 100 & RPS13 \\
\hline $40 S$ ribosomal protein S3 & 100 & RPS3 \\
\hline 5-beta-cholestane-3-alpha,7-alpha-diol 12-alpha-hydroxylase & 100 & CYP8B1 \\
\hline 60S ribosomal protein L14 & 100 & RPL14 \\
\hline $60 S$ ribosomal protein $\mathrm{L} 6$ & 100 & RPL6 \\
\hline Beta-crystallin B1 & 100 & CRYBB1 \\
\hline Dolichyl-diphosphooligosaccharide-protein glycosyltransferase subunit 2 & 100 & RPN2 \\
\hline Endoplasmic reticulum chaperone BiP & 100 & HSPA5 \\
\hline Glutamate carboxypeptidase 2 & 100 & FOLH1 \\
\hline Heat shock $70 \mathrm{kDa}$ protein $1 \mathrm{~A}$ & 100 & HSPA1A \\
\hline Heat shock $70 \mathrm{kDa}$ protein $1 \mathrm{~B}$ & 100 & HSPA1B \\
\hline Heat shock $70 \mathrm{kDa}$ protein 1 -like & 100 & HSPA1L \\
\hline Heme oxygenase 1 & 100 & HMOX1 \\
\hline Neutral alpha-glucosidase AB & 100 & GANAB \\
\hline Sarcoplasmic/endoplasmic reticulum calcium ATPase 2 & 100 & ATP2A2 \\
\hline Transitional endoplasmic reticulum ATPase & 100 & VCP \\
\hline Microsomal triglyceride transfer protein large subunit & 85 & MTTP \\
\hline Dolichyl-diphosphooligosaccharide-protein glycosyltransferase subunit 1 & 78 & RPN1 \\
\hline Dual oxidase 1 & 78 & DUOX1 \\
\hline Heat shock protein HSP 90-alpha & 78 & HSP90AA1 \\
\hline
\end{tabular}

Table A2. Membrane proteins depleted during decellularization.

\begin{tabular}{ccc}
\hline Membrane Proteins & \% Depletion & Gene Symbol \\
\hline ADP-ribosylation factor 6 & 100 & ARF6 \\
Arachidonate 15-lipoxygenase & 100 & ALOX15 \\
Calpain-1 catalytic subunit & 100 & CAPN1 \\
C-X-C chemokine receptor type 4 & 100 & CXCR4 \\
Cysteinyl leukotriene receptor 2 & 100 & CYSLTR2 \\
Desmoglein-1 & 100 & DSG1 \\
Endothelin-1 receptor & 100 & EDNRA \\
Gap junction alpha-1 protein & 100 & GJA1 \\
Geranylgeranyl transferase type-2 subunit alpha & RABGGTA \\
\hline
\end{tabular}


Table A2. Cont.

\begin{tabular}{|c|c|c|}
\hline Membrane Proteins & \% Depletion & Gene Symbol \\
\hline Glutathione hydrolase 1 proenzyme & 100 & GGT1 \\
\hline Growth hormone receptor & 100 & GHR \\
\hline Guanine nucleotide-binding protein $\mathrm{G}(\mathrm{q})$ subunit alpha & 100 & GNAQ \\
\hline Integrin beta-1 & 100 & ITGB1 \\
\hline Interferon alpha/beta receptor 1 & 100 & IFNAR1 \\
\hline Interleukin- 4 receptor subunit alpha & 100 & IL4R \\
\hline Interleukin-6 receptor subunit alpha & 100 & IL6R \\
\hline Low-density lipoprotein receptor & 100 & LDLR \\
\hline Mast/stem cell growth factor receptor Kit & 100 & KIT \\
\hline Metalloreductase STEAP1 & 100 & STEAP1 \\
\hline NT-3 growth factor receptor & 100 & NTRK3 \\
\hline Parathyroid hormone/parathyroid hormone-related peptide receptor & 100 & PTH1R \\
\hline PDZ domain-containing protein 11 & 100 & PDZD11 \\
\hline Plasma membrane calcium-transporting ATPase 1 & 100 & ATP2B1 \\
\hline Platelet endothelial cell adhesion molecule & 100 & PECAM1 \\
\hline Protocadherin-11 X-linked & 100 & PCDH11X \\
\hline Receptor activity-modifying protein 1 & 100 & RAMP1 \\
\hline S-Arrestin & 100 & SAG \\
\hline Sialoadhesin & 100 & SIGLEC1 \\
\hline SLA class II histocompatibility antigen, DQ haplotype C alpha chain & 100 & SLA-DQCA \\
\hline SLA class II histocompatibility antigen, DQ haplotype C beta chain & 100 & SLA-DQ̄CB \\
\hline SLA class II histocompatibility antigen, DQ haplotype D beta chain & 100 & SLA-DQDB \\
\hline Small conductance calcium-activated potassium channel protein 3 & 100 & KCNN3 \\
\hline Sodium/glucose cotransporter 1 & 100 & SLC5A1 \\
\hline Solute carrier family 22 member 6 & 100 & SLC22A6 \\
\hline Solute carrier family 22 member 7 & 100 & SLC22A7 \\
\hline Thyroid peroxidase & 100 & TPO \\
\hline Toll-like receptor 9 & 100 & TLR9 \\
\hline Transforming growth factor beta receptor type 3 & 100 & TGFBR3 \\
\hline Beta- 1 adrenergic receptor & 94 & ADRB1 \\
\hline Zonadhesin & 94 & ZAN \\
\hline Glutathione S-transferase alpha M14 & 94 & GSTAM14 \\
\hline Activin receptor type-2B & 93 & ACVR2B \\
\hline Solute carrier family 22 member 1 & 91 & SLC22A1 \\
\hline Low-density lipoprotein receptor-related protein 2 & 89 & LRP2 \\
\hline Orexin receptor type 2 & 89 & HCRTR2 \\
\hline Glutamate decarboxylase 2 & 89 & GAD2 \\
\hline Ectonucleotide pyrophosphatase/phosphodiesterase family member 6 & 85 & ENPP6 \\
\hline Tyrosine-protein kinase SYK & 85 & SYK \\
\hline Hormone-sensitive lipase & 85 & LIPE \\
\hline V-type proton ATPase catalytic subunit A & 85 & ATP6V1A \\
\hline Potassium-transporting ATPase alpha chain 1 & 82 & ATP4A \\
\hline Electrogenic sodium bicarbonate cotransporter 1 & 81 & SLC4A4 \\
\hline Alpha-2A adrenergic receptor & 78 & ADRA2A \\
\hline Calcium-activated chloride channel regulator 1 & 78 & CLCA1 \\
\hline Gastrin/cholecystokinin type B receptor & 78 & CCKBR \\
\hline Hepatocyte growth factor receptor & 78 & MET \\
\hline Leptin receptor & 78 & LEPR \\
\hline Extracellular calcium-sensing receptor & 70 & CASR \\
\hline Scavenger receptor class B member 1 & 70 & SCARB1 \\
\hline ATP-binding cassette sub-family G member 2 & 66 & ABCG2 \\
\hline Major facilitator superfamily domain-containing protein 6 & 66 & MFSD6 \\
\hline $\mathrm{H}(+) / \mathrm{Cl}(-)$ exchange transporter 5 & 63 & CLCN5 \\
\hline Prolactin receptor & 55 & PRLR \\
\hline Beta-3 adrenergic receptor & 55 & ADRB3 \\
\hline Lutropin-choriogonadotropic hormone receptor & 55 & LHCGR \\
\hline
\end{tabular}


Table A3. Cytosolic proteins depleted during decellularization.

\begin{tabular}{|c|c|c|}
\hline Cytosolic Proteins & \% Depletion & Gene Symbol \\
\hline 1-acylglycerol-3-phosphate O-acyltransferase ABHD5 & 100 & ABHD5 \\
\hline 4-hydroxyphenylpyruvate dioxygenase & 100 & HPD \\
\hline Actin, cytoplasmic 1 & 100 & ACTB \\
\hline Alcohol dehydrogenase [NADP(+)] & 100 & AKR1A1 \\
\hline Antileukoproteinase & 100 & SLPI \\
\hline ATP-dependent 6-phosphofructokinase, muscle type & 100 & PFKM \\
\hline Autophagy protein 5 & 100 & ATG5 \\
\hline Bifunctional epoxide hydrolase 2 & 100 & EPHX2 \\
\hline Biogenesis of lysosome-related organelles complex 1 subunit 5 & 100 & BLOC1S5 \\
\hline Calponin-1 OS = Sus scrofa & 100 & CNN1 \\
\hline Calponin-2 & 100 & CNN2 \\
\hline Cas scaffolding protein family member 4 & 100 & CASS4 \\
\hline Coatomer subunit beta & 100 & COPB1 \\
\hline Diacylglycerol kinase alpha & 100 & DGKA \\
\hline Dihydropyrimidine dehydrogenase [NADP $(+)]$ & 100 & DPYD \\
\hline FAST kinase domain-containing protein 4 & 100 & TBRG4 \\
\hline Gastrotropin & 100 & FABP6 \\
\hline Growth factor receptor-bound protein 10 & 100 & Grb10 \\
\hline Integrin beta-1-binding protein 2 & 100 & ITGB1BP2 \\
\hline L-dopachrome tautomerase & 100 & DCT \\
\hline L-lactate dehydrogenase A chain & 100 & LDHA \\
\hline Myosin light chain 4 & 100 & MYL4 \\
\hline Myosin-1 & 100 & MYH1 \\
\hline Myosin-2 & 100 & MYH2 \\
\hline Nucleoside diphosphate kinase B & 100 & NME2 \\
\hline Perilipin-3 & 100 & PLIN3 \\
\hline Phosphatidylinositol 4,5-bisphosphate 3-kinase catalytic subunit gamma isoform & 100 & PIK3CG \\
\hline Serine/threonine-protein phosphatase 2A $65 \mathrm{kDa}$ regulatory subunit A beta isoform & 100 & PPP2R1B \\
\hline Suppressor of cytokine signaling 2 & 100 & SOCS2 \\
\hline Thimet oligopeptidase & 100 & THOP1 \\
\hline Triosephosphate isomerase & 100 & TPI1 \\
\hline Tubulin alpha-1A chain & 100 & TUBA1A \\
\hline Tubulin beta chain & 100 & TUBB \\
\hline Vinculin & 100 & VCL \\
\hline Serine/threonine-protein kinase WNK1 & 95 & WNK1 \\
\hline L-lactate dehydrogenase B chain & 94 & LDHB \\
\hline UTP-glucose-1-phosphate uridylyltransferase & 92 & UGP2 \\
\hline Eukaryotic initiation factor $4 \mathrm{~A}-\mathrm{III}$ & 89 & EIF4A3 \\
\hline Triokinase/FMN cyclase & 85 & TKFC \\
\hline Acylphosphatase-1 & 83 & ACYP1 \\
\hline Glycine N-methyltransferase & 78 & GNMT \\
\hline $\mathrm{N}$-acetylneuraminate lyase & 78 & NPL \\
\hline Phosphatidylinositol 3-kinase catalytic subunit type 3 & 78 & PIK3C3 \\
\hline Serine/threonine-protein phosphatase 1 regulatory subunit 10 & 64 & PPP1R10 \\
\hline
\end{tabular}

\section{References}

1. Cross, M.; Smith, E.; Hoy, D.; Nolte, S.; Ackerman, I.; Fransen, M.; Bridgett, L.; Williams, S.; Guillemin, F.; Hill, C.L.; et al. The global burden of hip and knee osteoarthritis: Estimates from the Global Burden of Disease 2010 study. Ann. Rheum. Dis. 2014, 73, 1323-1330. [CrossRef] [PubMed]

2. Escobar Ivirico, J.L.; Bhattacharjee, M.; Kuyinu, E.; Nair, L.S.; Laurencin, C.T. Regenerative Engineering for Knee Osteoarthritis Treatment: Biomaterials and Cell-Based Technologies. Engineering 2017, 3, 16-27. [CrossRef]

3. Helmick, C.G.; Felson, D.T.; Lawrence, R.C.; Gabriel, S.; Hirsch, R.; Kwoh, C.K.; Liang, M.H.; Maradit Kremers, H.; Mayes, M.D.; Merkel, P.A.; et al. National Arthritis Data Workgroup Estimates of the prevalence of arthritis and other rheumatic conditions in the United States: Part I. Arthritis Rheum. 2008, 58, 15-25. [CrossRef]

4. Toh, W.S.; Foldager, C.B.; Pei, M.; Hui, J.H.P. Advances in Mesenchymal Stem Cell-based Strategies for Cartilage Repair and Regeneration. Stem Cell Rev. Rep. 2014, 10, 686-696. [CrossRef] 
5. Gupta, P.K.; Das, A.K.; Chullikana, A.; Majumdar, A.S. Mesenchymal stem cells for cartilage repair in osteoarthritis. Stem Cell Res. Ther. 2012, 3, 25. [CrossRef]

6. Goldberg, A.; Mitchell, K.; Soans, J.; Kim, L.; Zaidi, R. The use of mesenchymal stem cells for cartilage repair and regeneration: A systematic review. J. Orthop. Surg. Res. 2017, 12, 39. [CrossRef] [PubMed]

7. Cheng, C.W.; Solorio, L.D.; Alsberg, E. Decellularized tissue and cell-derived extracellular matrices as scaffolds for orthopaedic tissue engineering. Biotechnol. Adv. 2014, 32, 462-484. [CrossRef]

8. Djouad, F.; Mrugala, D.; Noël, D.; Jorgensen, C. Engineered mesenchymal stem cells for cartilage repair. Regen. Med. 2006, 1, 529-537. [CrossRef]

9. Guilak, F.; Nims, R.J.; Dicks, A.; Wu, C.-L.; Meulenbelt, I. Osteoarthritis as a disease of the cartilage pericellular matrix. Matrix Biol. 2010, 71-72, 40-50. [CrossRef]

10. Sophia Fox, A.J.; Bedi, A.; Rodeo, S.A. The basic science of articular cartilage: Structure, composition, and function. Sports Health 2009, 1, 461-468. [CrossRef]

11. Martin, J.A.; Buckwalter, J.A. Roles of articular cartilage aging and chondrocyte senescence in the pathogenesis of osteoarthritis. Iowa Orthop. J. 2001, 21, 1-7.

12. Schulze-Tanzil, G. Intraarticular Ligament Degeneration Is Interrelated with Cartilage and Bone Destruction in Osteoarthritis. Cells 2019, 8, 990. [CrossRef] [PubMed]

13. Loeser, R.F.; Goldring, S.R.; Scanzello, C.R.; Goldring, M.B. Osteoarthritis: A disease of the joint as an organ. Arthritis Rheum. 2012, 64, 1697-1707. [CrossRef] [PubMed]

14. Nam, Y.; Rim, Y.A.; Lee, J.; Ju, J.H. Current therapeutic strategies for stem cell-based cartilage regeneration. Stem Cells Int. 2018, 2018, 8490489. [CrossRef] [PubMed]

15. Baugé, C.; Boumédiene, K. Use of Adult Stem Cells for Cartilage Tissue Engineering: Current Status and Future Developments. Stem Cells Int. 2015, 2015, 438026. [CrossRef]

16. Ye, K.; Felimban, R.; Moulton, S.E.; Wallace, G.G.; Di Bella, C.; Traianedes, K.; Choong, P.F.M.; Myers, D.E. Bioengineering of articular cartilage: Past, present and future. Regen. Med. 2013, 8, 333-349. [CrossRef]

17. Huang, H.; Xu, H.; Zhang, J. Current Tissue Engineering Approaches for Cartilage Regeneration. In Cartilage Tissue Engineering and Regeneration Techniques; IntechOpen Limited: London, UK, 2019. [CrossRef]

18. Chang, B.; Cornett, A.; Nourmohammadi, Z.; Law, J.; Weld, B.; Crotts, S.J.; Hollister, S.J.; Lombaert, I.M.A.; Zopf, D.A. Hybrid Three-Dimensional-Printed Ear Tissue Scaffold With Autologous Cartilage Mitigates Soft Tissue Complications. Laryngoscope 2021, 131, 1008-1015. [CrossRef]

19. Gilpin, A.; Yang, Y. Decellularization Strategies for Regenerative Medicine: From Processing Techniques to Applications. BioMed Res. Int. 2017, 2017, 9831534. [CrossRef]

20. Heath, D.E. A Review of Decellularized Extracellular Matrix Biomaterials for Regenerative Engineering Applications. Regenerative Eng. Transl. Med. 2019, 5, 155-166. [CrossRef]

21. Kim, Y.S.; Majid, M.; Melchiorri, A.J.; Mikos, A.G. Applications of decellularized extracellular matrix in bone and cartilage tissue engineering. Bioeng. Transl. Med. 2019, 4, 83-95. [CrossRef]

22. Goldring, M.B.; Birkhead, J.R.; Suen, L.F.; Yamin, R.; Mizuno, S.; Glowacki, J.; Arbiser, J.L.; Apperley, J.F. Interleukin-1 $\beta$-modulated gene expression in immortalized human chondrocytes. J. Clin. Investig. 1994, 94, 2307-2316. [CrossRef] [PubMed]

23. Luo, L.; Eswaramoorthy, R.; Mulhall, K.J.; Kelly, D.J. Decellularization of porcine articular cartilage explants and their subsequent repopulation with human chondroprogenitor cells. J. Mech. Behav. Biomed. Mater. 2016, 55, 21-31. [CrossRef] [PubMed]

24. Steinberg, J.; Ritchie, G.R.S.; Roumeliotis, T.I.; Jayasuriya, R.L.; Clark, M.J.; Brooks, R.A.; Binch, A.L.A.; Shah, K.M.; Coyle, R.; Pardo, M.; et al. Integrative epigenomics, transcriptomics and proteomics of patient chondrocytes reveal genes and pathways involved in osteoarthritis. Sci. Rep. 2017, 7, 8935. [CrossRef] [PubMed]

25. Valdes, A.M. Involvement of the CLEC3B gene in osteoarthritis. Osteoarthr. Cartil. 2011, 19, 249. [CrossRef]

26. Karlsson, C.; Dehne, T.; Lindahl, A.; Brittberg, M.; Pruss, A.; Sittinger, M.; Ringe, J. Genome-wide expression profiling reveals new candidate genes associated with osteoarthritis. Osteoarthr. Cartil. 2010, 18, 581-592. [CrossRef]

27. Mazzoni, E.; D’Agostino, A.; Iaquinta, M.R.; Bononi, I.; Trevisiol, L.; Rotondo, J.C.; Patergnani, S.; Giorgi, C.; Gunson, M.J.; Arnett, G.W.; et al. Hydroxylapatite-collagen hybrid scaffold induces human adipose-derived mesenchymal stem cells to osteogenic differentiation in vitro and bone regrowth in patients. Stem Cells Transl. Med. 2020, 9, 377-388. [CrossRef]

28. Johnson, K.; Reynard, L.N.; Loughlin, J. Functional characterisation of the osteoarthritis susceptibility locus at chromosome 6q14.1 marked by the polymorphism rs9350591. BMC Med. Genet. 2015, 16, 81. [CrossRef]

29. arcOGEN Consortium; arcOGEN Collaborators; Zeggini, E.; Panoutsopoulou, K.; Southam, L.; Rayner, N.W.; Day-Williams, A.G.; Lopes, M.C.; Boraska, V.; Esko, T.; et al. Identification of new susceptibility loci for osteoarthritis (arcOGEN): A genome-wide association study. Lancet 2012, 380, 815-823. [CrossRef] [PubMed]

30. Manon-Jensen, T.; Karsdal, M.A. Type XII Collagen. In Biochemistry of Collagens, Laminins and Elastin: Structure, Function and Biomarkers; Elsevier Inc.: Amsterdam, The Netherlands, 2016; pp. 81-85.

31. Luo, Y.; Sinkeviciute, D.; He, Y.; Karsdal, M.; Henrotin, Y.; Mobasheri, A.; Önnerfjord, P.; Bay-Jensen, A. The minor collagens in articular cartilage. Protein Cell 2017, 8, 560-572. [CrossRef] 
32. Agarwal, P.; Zwolanek, D.; Keene, D.R.; Schulz, J.-N.; Blumbach, K.; Heinegård, D.; Zaucke, F.; Paulsson, M.; Krieg, T.; Koch, M.; et al. Collagen XII and XIV, new partners of cartilage oligomeric matrix protein in the skin extracellular matrix suprastructure. J. Biol. Chem. 2012, 287, 22549-22559. [CrossRef] [PubMed]

33. Zhou, Z.; Sheng, X.; Zhang, Z.; Zhao, K.; Zhu, L.; Guo, G.; Friedenberg, S.G.; Hunter, L.S.; Vandenberg-Foels, W.S.; Hornbuckle, W.E.; et al. Differential genetic regulation of canine hip dysplasia and osteoarthritis. PLoS ONE 2010, 5, e13219. [CrossRef]

34. Tang, X.; Muhammad, H.; McLean, C.; Miotla-Zarebska, J.; Fleming, J.; Didangelos, A.; Önnerfjord, P.; Leask, A.; Saklatvala, J.; Vincent, T.L. Connective tissue growth factor contributes to joint homeostasis and osteoarthritis severity by controlling the matrix sequestration and activation of latent TGF $\beta$. Ann. Rheum. Dis. 2018, 77, 1372-1380. [CrossRef] [PubMed]

35. Ivkovic, S.; Yoon, B.S.; Popoff, S.N.; Safadi, F.F.; Libuda, D.E.; Stephenson, R.C.; Daluiski, A.; Lyons, K.M. Connective tissue growth factor coordinates chondrogenesis and angiogenesis during skeletal development. Development 2003, 130, $2779-2791$. [CrossRef] [PubMed]

36. Shi-Wen, X.; Leask, A.; Abraham, D. Regulation and function of connective tissue growth factor/CCN2 in tissue repair, scarring and fibrosis. Cytokine Growth Factor Rev. 2008, 19, 133-144. [CrossRef] [PubMed]

37. Lipson, K.E.; Wong, C.; Teng, Y.; Spong, S. CTGF is a central mediator of tissue remodeling and fibrosis and its inhibition can reverse the process of fibrosis. Fibrogenes. Tissue Repair 2012, 5, S24. [CrossRef] [PubMed]

38. Kong, L.; Zhao, Y.P.; Tian, Q.Y.; Feng, J.-Q.; Kobayashi, T.; Merregaert, J.; Liu, C.-J. Extracellular matrix protein 1, a direct targeting molecule of parathyroid hormone-related peptide, negatively regulates chondrogenesis and endochondral ossification via associating with progranulin growth factor. FASEB J. 2016, 30, 2741-2754. [CrossRef]

39. Mongiat, M.; Fu, J.; Oldershaw, R.; Greenhalgh, R.; Gown, A.M.; Iozzo, R.V. Perlecan protein core interacts with extracellular matrix protein 1 (ECM1), a glycoprotein involved in bone formation and angiogenesis. J. Biol. Chem. 2003, 278, 17491-17499. [CrossRef]

40. Frahs, S.M.; Reeck, J.C.; Yocham, K.M.; Frederiksen, A.; Fujimoto, K.; Scott, C.M.; Beard, R.S., Jr.; Brown, R.J.; Lujan, T.J.; Solov'yov, I.A.; et al. Prechondrogenic ATDC5 Cell Attachment and Differentiation on Graphene Foam; Modulation by Surface Functionalization with Fibronectin. ACS Appl. Mater. Interfaces 2019, 11, 41906-41924. [CrossRef]

41. Kong, L.; Tian, Q.; Guo, F.; Mucignat, M.T.; Perris, R.; Sercu, S.; Merregaert, J.; Di Cesare, P.E.; Liu, C.-J. Interaction between cartilage oligomeric matrix protein and extracellular matrix protein 1 mediates endochondral bone growth. Matrix Biol. 2010, 29, 276-286. [CrossRef]

42. Yatabe, T.; Mochizuki, S.; Takizawa, M.; Chijiiwa, M.; Okada, A.; Kimura, T.; Fujita, Y.; Matsumoto, H.; Toyama, Y.; Okada, Y. Hyaluronan inhibits expression of ADAMTS4 (aggrecanase-1) in human osteoarthritic chondrocytes. Ann. Rheum. Dis. 2009, 68, 1051-1058. [CrossRef]

43. Gromova, O.A.; Torshin, I.Y.; Lila, A.M.; Gromov, A.N. Molecular mechanisms of action of glucosamine sulfate in the treatment of degenerative-dystrophic diseases of the joints and spine: Results of proteomic analysis. Nevrol. Neiropsikhiatriya Psikhosomatika 2018, 10, 38-44. [CrossRef]

44. Rangkasenee, N.; Murani, E.; Schellander, K.; Cinar, M.U.; Ponsuksili, S.; Wimmers, K. Gene expression profiling of articular cartilage reveals functional pathways and networks of candidate genes for osteochondrosis in pigs. Physiol. Genom. 2013, 45, 856-865. [CrossRef]

45. Zhang, R.; Guo, H.; Yang, X.; Li, Z.; Zhang, D.; Li, B.; Zhang, D.; Li, Q.; Xiong, Y. Potential candidate biomarkers associated with osteoarthritis: Evidence from a comprehensive network and pathway analysis. J. Cell. Physiol. 2019, 234, 17433-17443. [CrossRef]

46. Djouad, F.; Delorme, B.; Maurice, M.; Bony, C.; Apparailly, F.; Louis-Plence, P.; Canovas, F.; Charbord, P.; Noël, D.; Jorgensen, C. Microenvironmental changes during differentiation of mesenchymal stem cells towards chondrocytes. Arthritis Res. Ther. 2007, 9, R33. [CrossRef] [PubMed]

47. Weeks, S.; Kulkarni, A.; Smith, H.; Whittall, C.; Yang, Y.; Middleton, J. The effects of chemokine, adhesion and extracellular matrix molecules on binding of mesenchymal stromal cells to poly(l-lactic acid). Cytotherapy 2012, 14, 1080-1088. [CrossRef] [PubMed]

48. Zhu, Z.; Chen, G.; Jiao, W.; Wang, D.; Cao, Y.; Zhang, Q.; Wang, J. Identification of critical genes in nucleus pulposus cells isolated from degenerated intervertebral discs using bioinformatics analysis. Mol. Med. Rep. 2017, 16, 553-564. [CrossRef]

49. Tu, Y.; Ma, T.; Wen, T.; Yang, T.; Xue, L.; Cai, M.; Wang, F.; Guan, M.; Xue, H. MicroRNA-377-3p alleviates IL-1 $\beta$-caused chondrocyte apoptosis and cartilage degradation in osteoarthritis in part by downregulating ITGA6. Biochem. Biophys. Res. Commun. 2020, 523, 46-53. [CrossRef] [PubMed]

50. LaPointe, V.L.S.; Verpoorte, A.; Stevens, M.M. The changing integrin expression and a role for integrin $\beta 8$ in the chondrogenic differentiation of mesenchymal stem cells. PLoS ONE 2013, 8, e82035. [CrossRef]

51. Wang, A.; Chen, M.; Wang, H.; Huang, J.; Bao, Y.; Gan, X.; Liu, B.; Lu, X.; Wang, L. Cell Adhesion-Related Molecules Play a Key Role in Renal Cancer Progression by Multinetwork Analysis. BioMed Res. Int. 2019, 2019, 2325765. [CrossRef]

52. Soki, F.N.; Yoshida, R.; Paglia, D.N.; Duong, L.T.; Hansen, M.F.; Drissi, H. Articular cartilage protection in Ctsk ${ }^{-/-}$mice is associated with cellular and molecular changes in subchondral bone and cartilage matrix. J. Cell. Physiol. 2018, 233, 8666-8676. [CrossRef] [PubMed]

53. Adapala, N.S.; Kim, H.K.W. Comprehensive genome-wide transcriptomic analysis of immature articular cartilage following ischemic osteonecrosis of the femoral head in piglets. PLoS ONE 2016, 11, e0153174. [CrossRef]

54. Grogan, S.P.; Duffy, S.F.; Pauli, C.; Koziol, J.A.; Su, A.I.; D’Lima, D.D.; Lotz, M.K. Zone-specific gene expression patterns in articular cartilage. Arthritis Rheum. 2013, 65, 418-428. [CrossRef] 
55. Mann, V.; Grimm, D.; Corydon, T.J.; Krüger, M.; Wehland, M.; Riwaldt, S.; Sahana, J.; Kopp, S.; Bauer, J.; Reseland, J.E.; et al. Changes in human foetal osteoblasts exposed to the random positioning machine and bone construct tissue engineering. Int. J. Mol. Sci. 2019, 20, 1357. [CrossRef]

56. Dehne, T.; Schenk, R.; Perka, C.; Morawietz, L.; Pruss, A.; Sittinger, M.; Kaps, C.; Ringe, J. Gene expression profiling of primary human articular chondrocytes in high-density micromasses reveals patterns of recovery, maintenance, re- and dedifferentiation. Gene 2010, 462, 8-17. [CrossRef]

57. Göhring, A.R.; Lübke, C.; Andreas, K.; Kaps, C.; Häupl, T.; Pruss, A.; Perka, C.; Sittinger, M.; Ringe, J. Tissue-engineered cartilage of porcine and human origin as in vitro test system in arthritis research. Biotechnol. Prog. 2010, 26, 1116-1125. [CrossRef] [PubMed]

58. Lv, F.J.; Peng, Y.; Lim, F.L.; Sun, Y.; Lv, M.; Zhou, L.; Wang, H.; Zheng, Z.; Cheung, K.; Leung, V. Matrix metalloproteinase 12 is an indicator of intervertebral disc degeneration co-expressed with fibrotic markers. Osteoarthr. Cartil. 2016, 24, 1826-1836. [CrossRef]

59. Challa, T.D.; Rais, Y.; Ornan, E.M. Effect of adiponectin on ATDC5 proliferation, differentiation and signaling pathways. Mol. Cell. Endocrinol. 2010, 323, 282-291. [CrossRef]

60. Yang, Q.; Attur, M.; Kirsch, T.; Lee, Y.L.; Yakar, S.; Liu, Z.; Abramson, S.B.; Mignatti1, P. Membrane-type 1 matrix metalloproteinase controls osteo-and chondrogenesis by a proteolysis-independent mechanism mediated by its cytoplasmic tail. Osteoarthr. Cartil. 2015, 23, A64. [CrossRef]

61. Miao, D.; Bai, X.; Panda, D.K.; Karaplis, A.C.; Goltzman, D.; McKee, M.D. Cartilage abnormalities are associated with abnormal Phex expression and with altered matrix protein and MMP-9 localization in Hyp mice. Bone 2004, 34, 638-647. [CrossRef] [PubMed]

62. Gari, M.A.; AlKaff, M.; Alsehli, H.S.; Dallol, A.; Gari, A.; Abu-Elmagd, M.; Kadam, R.; Abuzinadah, M.F.; Gari, M.; Abuzenadah, A.M.; et al. Identification of novel genetic variations affecting osteoarthritis patients. BMC Med. Genet. 2016, 17, 68. [CrossRef]

63. Rouillard, A.D.; Gundersen, G.W.; Fernandez, N.F.; Wang, Z.; Monteiro, C.D.; McDermott, M.G.; Ma'ayan, A. The harmonizome: A collection of processed datasets gathered to serve and mine knowledge about genes and proteins. Database J. Biol. Databases Curation 2016, 2016, baw100. [CrossRef] [PubMed]

64. Bonn, F.; Pantakani, K.; Shoukier, M.; Langer, T.; Mannan, A.U. Functional evaluation of paraplegin mutations by a yeast complementation assay. Hum. Mutat. 2010, 31, 617-621. [CrossRef] [PubMed]

65. Vos, H.L.; Devarayalu, S.; De Vries, Y.; Bornstein, P. Thrombospondin 3 (Thbs3), a new member of the thrombospondin gene family. J. Biol. Chem. 1992, 267, 12192-12196. [CrossRef]

66. Adolph, K.W.; Long, G.L.; Winfield, S.; Ginns, E.I.; Bornstein, P. Structure and organization of the human thrombospondin 3 gene (thbs3). Genomics 1995, 27, 329-336. [CrossRef]

67. Posey, K.L.; Hankenson, K.; Veerisetty, A.C.; Bornstein, P.; Lawler, J.; Hecht, J.T. Skeletal abnormalities in mice lacking extracellular matrix proteins, thrombospondin-1, thrombospondin-3, thrombospondin-5, and type IX collagen. Am. J. Pathol. 2008, 172, 1664-1674. [CrossRef]

68. Hankenson, K.D.; Hormuzdi, S.G.; Meganck, J.A.; Bornstein, P. Mice with a Disruption of the Thrombospondin 3 Gene Differ in Geometric and Biomechanical Properties of Bone and Have Accelerated Development of the Femoral Head. Mol. Cell. Biol. 2005, 25, 5599-5606. [CrossRef] [PubMed]

69. Kamiya, N.; Watanabe, H.; Habuchi, H.; Takagi, H.; Shinomura, T.; Shimizu, K.; Kimata, K. Versican/PG-M regulates chondrogenesis as an extracellular matrix molecule crucial for mesenchymal condensation. J. Biol. Chem. 2006, 281, 2390-2400. [CrossRef] [PubMed]

70. Choocheep, K.; Hatano, S.; Takagi, H.; Watanabe, H.; Kimata, K.; Kongtawelert, P.; Watanabe, H. Versican facilitates chondrocyte differentiation and regulates joint morphogenesis. J. Biol. Chem. 2010, 285, 21114-21125. [CrossRef]

71. Sztrolovics, R.; Grover, J.; Cs-Szabo, G.; Shi, S.L.; Zhang, Y.; Mort, J.S.; Roughley, P.J. The characterization of versican and its message in human articular cartilage and intervertebral disc. J. Orthop. Res. 2002, 20, 257-266. [CrossRef]

72. Luo, H.; Yao, L.; Zhang, Y.; Li, R. Liquid chromatography-mass spectrometry-based quantitative proteomics analysis reveals chondroprotective effects of astragaloside IV in interleukin-1 $\beta$-induced SW1353 chondrocyte-like cells. Biomed. Pharmacother. 2017, 91, 796-802. [CrossRef]

73. Vieira, A.E.; Repeke, C.E.; De Barros Ferreira, S.; Colavite, P.M.; Biguetti, C.C.; Oliveira, R.C.; Assis, G.F.; Taga, R.; Trombone, A.P.; Garlet, G.P. Intramembranous bone healing process subsequent to tooth extraction in mice: Micro-computed tomography, histomorphometric and molecular characterization. PLoS ONE 2015, 10, e0128021. [CrossRef] [PubMed]

74. Pei, M.; Zhang, Y.; Li, J.; Chen, D. Antioxidation of decellularized stem cell matrix promotes human synovium-derived stem cell-based chondrogenesis. Stem Cells Dev. 2013, 22, 889-900. [CrossRef]

75. Schwarz, S.; Koerber, L.; Elsaesser, A.F.; Goldberg-Bockhorn, E.; Seitz, A.M.; Dürselen, L.; Ignatius, A.; Walther, P.; Breiter, R.; Rotter, N. Decellularized cartilage matrix as a novel biomatrix for cartilage tissue-engineering applications. Tissue Eng. Part $A$ 2012, 18, 2195-2209. [CrossRef] [PubMed]

76. Xu, H.; Xu, B.; Yang, Q.; Li, X.; Ma, X.; Xia, Q.; Zhang, Y.; Zhang, C.; Wu, Y.; Zhang, Y. Comparison of decellularization protocols for preparing a decellularized porcine annulus fibrosus scaffold. PLoS ONE 2014, 9, e86723. [CrossRef] [PubMed]

77. Kiyotake, E.A.; Beck, E.C.; Detamore, M.S. Cartilage extracellular matrix as a biomaterial for cartilage regeneration. Ann. N. Y. Acad. Sci. 2016, 1383, 139-159. [CrossRef] [PubMed] 
78. Peretti, G.M.; Randolph, M.A.; Caruso, E.M.; Rossetti, F.; Zaleske, D.J. Bonding of cartilage matrices with cultured chondrocytes: An experimental model. J. Orthop. Res. 1998, 16, 89-95. [CrossRef]

79. Vas, W.J.; Shah, M.; Blacker, T.S.; Duchen, M.R.; Sibbons, P.; Roberts, S.J. Decellularized Cartilage Directs Chondrogenic Differentiation: Creation of a Fracture Callus Mimetic. Tissue Eng. Part A 2018, 24, 1364-1376. [CrossRef]

80. Li, J.; Pei, M. Cell Senescence: A Challenge in Cartilage Engineering and Regeneration. Tissue Eng. Part. B Rev. 2012, 18, $270-287$. [CrossRef]

81. Gong, Y.Y.; Xue, J.X.; Zhang, W.J.; Zhou, G.D.; Liu, W.; Cao, Y. A sandwich model for engineering cartilage with acellular cartilage sheets and chondrocytes. Biomaterials 2011, 32, 2265-2273. [CrossRef] 